\title{
Early to Mid-Miocene syn-extensional massive silicic volcanism in the Pannonian Basin (East-Central Europe): Eruption chronology, correlation potential and geodynamic implications
}

\author{
Réka Lukács $^{\mathrm{a}, *, \text { Szabolcs Harangi }{ }^{\mathrm{a}, \mathrm{b}} \text {, Marcel Guillong }}{ }^{\mathrm{c}}$, Olivier Bachmann ${ }^{\mathrm{c}}$, László Fodor ${ }^{\mathrm{a}, ~ d}$, Yannick Buret ${ }^{\mathrm{c}, \mathrm{e}}$, \\ István Dunkl ${ }^{\mathrm{f}}$, Jakub Sliwinski ${ }^{\mathrm{c}}$, Albrecht von Quadt ${ }^{\mathrm{c}}$, Irena Peytcheva ${ }^{\mathrm{c}}$, Matthew Zimmerer ${ }^{\mathrm{g}}$ \\ ${ }^{a}$ MTA-ELTE Volcanology Research Group, 1117, Budapest Pázmány Péter sétány 1/C, Budapest, Hungary \\ ${ }^{\mathrm{b}}$ Department of Petrology and Geochemistry, Eötvös Loránd University, 1117, Budapest Pázmány Péter sétány 1/C, Budapest, Hungary \\ ${ }^{c}$ Institute of Geochemistry and Petrology, Department of Earth Sciences, ETH Zürich, Clausius strasse 25, 8092 Zürich, Switzerland \\ d MTA-ELTE Geological, Geophysical and Space Science Research, 1117, Budapest Pázmány Péter sétány 1/C, Budapest, Hungary \\ e Core Research Laboratories, Natural History Museum, Cromwell Road, London SW7 5BD, UK \\ ${ }^{f}$ Sedimentology \& Environmental Geology, Geoscience Center, University of Göttingen, Goldschmidtstrasse 3, D-37077 Göttingen, Germany \\ ${ }^{g}$ New Mexico Bureau of Geology and Mineral Resources, 801 Leroy Pl, Socorro, NM 87801, USA
}

\section{A R T I CLE INFO}

\section{Keywords:}

Silicic ignimbrite

Pannonian Basin

Bükkalja Volcanic Field

Zircon ages

Eruption chronology

Paratethys

syn-extensional volcanism

\begin{abstract}
A B S T R A C T
Formation and evolution of the Pannonian Basin as part of the Mediterranean region was accompanied by eruptions of compositionally diverse magmas during the Neogene to Quaternary. The long-lasting magmatic activity began with some of the most voluminous silicic eruptions in Europe for the last $20 \mathrm{Myr}$. This paper describes the eruption chronology of this volcanic activity using new, high-quality zircon U-Pb dates, and provides the first estimates on the volume and areal distribution of the volcanic products, characterizes the magma composition and discusses the silicic magmatism in a region, where the continental lithosphere underwent significant extension. A thorough zircon geochronological study was conducted on samples collected from ignimbrites and pyroclastic fall deposits exposed in the Bükkalja Volcanic Field. In-situ LA-ICP-MS analysis on zircon grains provided a fast, cheap and accurate method for such detailed geochronological work, where the volcanic products occur in scattered outcrops that often have poor stratigraphic constraints. The interpreted eruption ages were determined from the youngest zircon age population within the samples and this methodology was validated by new single zircon CA-ID-TIMS dates and sanidine Ar-Ar ages. The volcanism covers about $4 \mathrm{Myrs}$, from 18.2 Ma to $14.4 \mathrm{Ma}$ and involved at least eight eruptive phases. Within this, four large eruption events were recognized at $14.358 \pm 0.015 \mathrm{Ma}$ (Harsány ignimbrite), $14.880 \pm 0.014 \mathrm{Ma}$ (Demjén ignimbrite), 16.816 \pm 0.059 Ma (Bogács unit) and 17.055 $\pm 0.024 \mathrm{Ma}$ (Mangó ignimbrite), which are found in areas across the Pannonian Basin and elsewhere in central Europe. Considering all the potential sources of silicic ash found in the Paratethys sub-basins around the Pannonian Basin and along the northern Alps and in central Italy, we suggest that they were probably derived almost exclusively from the Pannonian Basin as shown by zircon U-Pb dates presented in this paper and published comparable age data from several localities. The new eruption ages considerably refine the Early to Mid-Miocene chronostratigraphy of the Pannonian basin, where the extensive volcanoclastic horizons are used as important marker layers.

The cumulative volume of the volcanic material formed during this $4 \mathrm{Myr}$ long silicic volcanism is estimated to be $>4000 \mathrm{~km}^{3}$, consistent with a significant ignimbrite flare-up event. Zircon crystallization ages indicate magma intrusions and formations of magma reservoirs in the continental crust for prolonged period, likely $>1 \mathrm{Myr}$ prior to the onset of the silicic volcanism accompanied with sporadic andesitic to dacitic volcanic activities. Mafic magmas were formed by melting of the thinned lithospheric mantle metasomatized previously by subduction-related fluids and emplaced at the crust-mantle boundary. They evolved further by assimilation and fractional crystallization to generate silicic magmas, which ascended into the pre-warmed upper crust and
\end{abstract}

\footnotetext{
* Corresponding author.

Email address: reka.harangi@gmail.com (R. Lukács)
} 
formed extended magma storage regions. Zircon Hf isotope and bulk rock Sr-Nd isotopic data indicate a sharp decrease of crustal and/or increase of asthenospheric mantle input after 16.2 Ma, suggesting that by this time the crust, and the lithospheric mantle was considerably thinned. This magmatism appears to have had a structural relationship to tectonic movements characterized by strike-slip and normal faults within the Mid-Hungarian Shear Zone as well as vertical axis block rotations, when the two microplates were juxtaposed. Our new zircon ages helped to refine the age of two major block-rotation phases associated with faulting. This volcanism shows many similarities with other rift-related silicic volcanic activities such as the Taupo Volcanic Zone (New Zealand) and the Basin and Range Province (USA).

\section{Introduction}

Understanding the nature and geodynamic conditions of silicic volcanism that can generate multiple caldera-forming events, and occasionally lead to ignimbrite flare-up episodes, remains a challenging task in Earth sciences (e.g., Hildreth, 1981; Houghton et al., 1995; Hildreth and Wilson, 2007; Bachmann and Bergantz, 2008; de Silva, 2008; Folkes et al., 2011; Schmitt et al., 2011; Hughes and Mahood, 2011; Best et al., 2013; de Silva et al., 2015; Lipman and Bachmann, 2015; Bachmann and Huber, 2016; Gravley et al., 2016; Thouret et al., 2016). Such volcanic activity occurs in various tectonic settings, preferentially within thick continental crust, although massive silicic volcanism is also related to regions where continental rifting has led to thin crust and lithosphere. Understanding the interplay of magmatism, volcanism and tectonic processes, as well as the thermomechanical response of the continental crust, is crucial to gain more knowledge on the evolution of continental crust in a given area (de Silva and Gregg, 2014; de Silva et al., 2015; Karakas and Dufek, 2015; Gravley et al., 2016; Karakas et al., 2017).

The Mediterranean area and its surroundings have been characterized by a wide range of volcanic activity and magma types from Neogene to recent times (Wilson and Bianchini, 1999; Peccerillo, 2005; Harangi et al., 2006; Lustrino and Wilson, 2007; Conticelli et al., 2009; Carminati et al., 2010; Lustrino et al., 2011), reflecting the complex geodynamic evolution of this area (Gueguen et al., 1998; Jolivet and Faccenna, 2000; Jolivet et al., 2008; Carminati et al., 2012). The Carpathian-Pannonian Region (east-central Europe) shows many elements of this evolution and thus, is an excellent natural laboratory in which the magmatism formed by the interaction between tectonic and deep mantle processes can be studied in detail (Harangi and Lenkey, 2007; Seghedi and Downes, 2011; and references therein). Formation of the Pannonian Basin by major lithosphere-scale stretching was associated with massive silicic volcanism. Although this silicic volcanic activity appears to have been the largest in Europe during the Miocene, and certainly had a major impact on the region, it is much less studied compared to the subsequent calc-alkaline and alkaline volcanism of this region (Seghedi et al., 2004; Harangi et al., 2015; and references therein). In this paper, we define and describe this massive silicic volcanic episode, particularly focusing on its eruption chronology, the possible regional correlation of the dispersed tephra, the development of silicic magmatism during continental extension, the temporal changes in magma composition and its geodynamic and tectonic relations. These new results could promote further research to determine how the continental crust reacted to the extensive magmatic and tectonic events and how volcanic ash deposits can be used to constrain better the regional Paratethys chronostratigraphy in Europe.

Precisely determining eruption ages requires suitable mineral phases and sufficiently precise and accurate analytical techniques. Zircon is a common accessory mineral in silicic volcanic products that can easily be dated by U-Pb geochronology. It is resistant to mechanical and chemical erosion and therefore can also be dated from altered distal volcanic deposits, such as bentonites, enabling correlation of eruption products on a regional scale. Zircon-based geochronology is widely used to determine crystallization timescales (e.g., Reid et al., 1997;
Schmitt, 2009; Schmitt et al., 2011; Schoene et al., 2010; Cooper, 2015), due to the high closure temperature $\left(>900^{\circ} \mathrm{C}\right)$ for $\mathrm{U}$, Th and $\mathrm{Pb}$ in zircons (Cherniak et al., 1997). However, these dates do not necessarily indicate the eruption age because of the inferred long lifetime of silicic magma reservoirs (Costa, 2008; Reid, 2008; Bachmann et al., 2007; Cooper and Kent, 2014). Hence, careful evaluation is required to properly interpret the spread in zircon dates from a single eruption.

Several techniques are available to date zircons by U-Pb geochronology. The most precise is ID-TIMS (e.g., Crowley et al., 2007; Schoene et al., 2013; Wotzlaw et al., 2014), although this method is time-consuming and has low spatial resolution. In-situ LA-ICP-MS and SHRIMP/SIMS methods, have the advantage of high sample throughput and spatial resolution, albeit at the expense of analytical precision. Here, we demonstrate that LA-ICP-MS zircon dating, complemented by zircon ID-TIMS and sanidine ${ }^{40} \mathrm{Ar} /{ }^{39} \mathrm{Ar}$ dating is a powerful technique in constructing a detailed eruption chronology of a complex volcanic area.

Results of LA-ICP-MS zircon dating for the youngest phases of the Early to Mid-Miocene silicic volcanism in the Pannonian Basin were published by Lukács et al. (2015). The current study expands the database with new age determinations for the older eruptive events and provides Hf isotopic values and bulk rock compositions, which characterize the entire period of silicic volcanism. These data form the basis for a regional zircon perspective correlation for scattered volcanic ash-bearing sedimentary deposits, accumulated in various sub-basins along the northern Mediterranean (Alpine forelands) during the Paratethys era (e.g. Rocholl et al., 2017). Correlation and chronostratigraphy of Mid-Miocene sedimentary deposits help to refine local lithostratigraphy and the regional stages of the Paratethys, and contribute to connecting the sequences to global events (i.e. precise timing and cross-correlation of geomagnetic polarity reversals, sea-level cycles, astronomic and climatic events, flora and fauna evolutional stages). With these new results we highlight the importance of this relatively less well known massive silicic Miocene volcanism which occurred during a very active geodynamic period in Europe.

\section{Geological setting}

\subsection{The Carpathian Pannonian Region}

The Carpathian-Pannonian Region is composed of two continental microplates (Alcapa and Tisza-Dacia) which have distinct pre-Miocene palaeogeographic positions and histories (Balla, 1984; Csontos et al., 1992). The Alcapa block was extruded from the Alpine contractional orogen by major transpressional strike-slip faulting during the latest Oligocene-Early Miocene (Csontos and Nagymarosy, 1998; Fodor et al., 1998). The two continental microplates were juxtaposed along a dextral transpressional fault zone (Mid-Hungarian shear Zone; MHZ, Fig. 1a; Balla, 1984; Csontos and Nagymarosy, 1998; Fodor et al., 1998), just before or during the first rifting event, from ca. 23 to $15 \mathrm{Ma}$. During this time, the major continental blocks gradually occupied the area of the Carpathian embayment, with a northeast- to eastward movement (Balla, 1984; Ustaszewski et al., 2008) and by associated vertical-axis rotations (Csontos et al., 1992; Márton and Márton, 

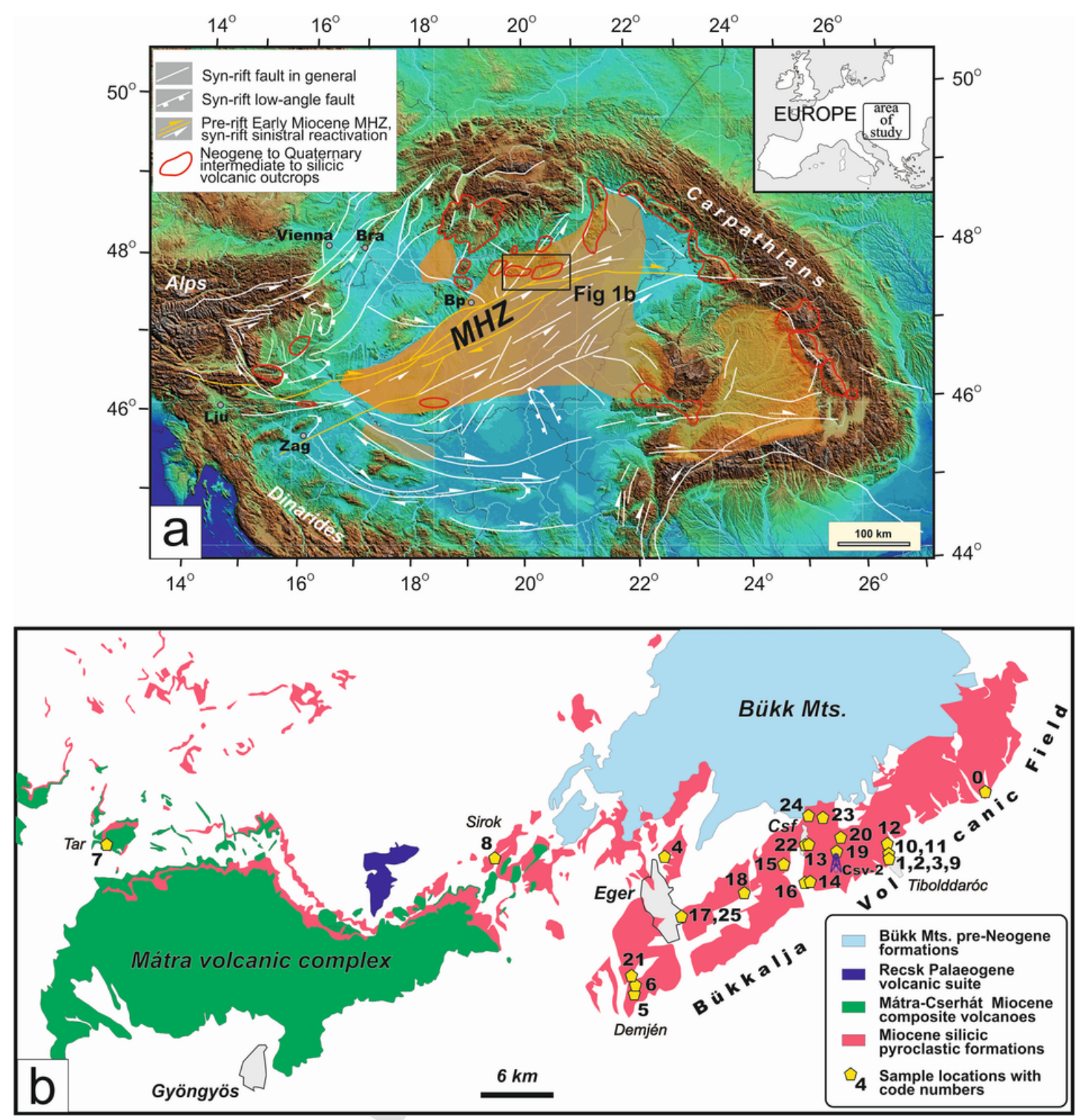

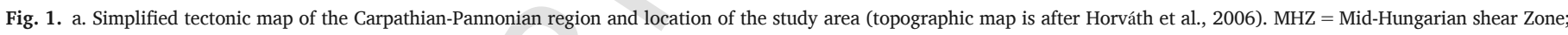

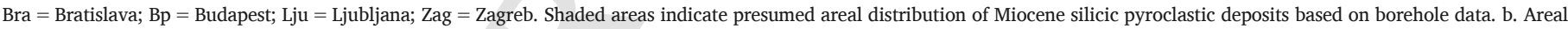

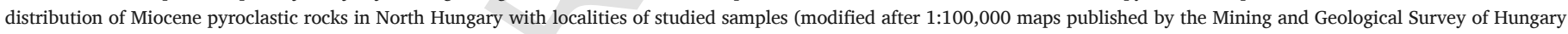
in https://map.mfgi.hu/fdt100/). Code numbers of localities are found in ESM_1. Csf = Cserépfalu. Csv-2: site of the borehole.

1996; Fodor et al., 1999). The Pannonian Basin was formed by significant thinning of the lithosphere in the hinterland of the Carpathian-Dinaridic orogens during the Miocene (Royden et al., 1982; Horváth, 1993; Tari et al., 1999; Horváth et al., 2006, 2015). Although it is widely considered as a continental back-arc basin (e.g., Royden et al., 1983; Doglioni, 1992; Horváth, 1993; Konečný et al., 2002; Balázs et al., 2016, 2017), the subduction process along the Carpathians has been recently debated (Gemmer and Houseman, 2007; Houseman and Gemmer, 2007; Fillerup et al., 2010; Dando et al., 2011). Major phase of normal faulting culminated diachronously in different parts of the Pannonian Basin; possibly already at $28 \mathrm{Ma}$ near the southwestern margin, and ca. 19Ma around the study area, in the western and northern basin parts, and only at about 10-9 Ma in the eastern sub-basins. (Royden et al., 1982; Csontos, 1995; Fodor et al., 1999; Tari et al., 1999; Matenco and Radivojević, 2012; Horváth et al., 2015; Balázs et al., 2016). Analysis of seismic sections provide evidence that cessation of extension (onset of the post-rift phase) was also diachronous within the basin, starting at ca. $14.8 \mathrm{Ma}$ in the south-western and 9-8 Ma in the eastern basin parts (Tari et al., 1999; Balázs et al., 2016). Driving forces of the regional extension are thought to have been the suction derived from subduction roll-back (Royden, 1993; Csontos et al., 1992; Nemčok et al., 1998), combined with asthenospheric mantle flow and/ or lithospheric delamination (Houseman and Gemmer, 2007; Kovács et al., 2012; Horváth et al., 2015). Numerical modelling shows that lithospheric attenuation and the associated magmatism were connected to convective upwelling of the asthenosphere (Huismans et al., 2001; Balázs et al., 2017) which resulted in high maturity level of organic matter, the still high heat flow and the geothermal resources of the area (Lenkey et al., 2002; Horváth et al., 2015). The rifting process was followed by major subsidence and neotectonic inversion (Dombrádi et al., 2010; Horváth et al., 2015).

The Miocene tectonic evolution of the Carpathian-Pannonian Region was associated with intense volcanic activity involving compositionally variable magmas (Szabó et al., 1992; Harangi, 2001; Konečný 
et al., 2002; Seghedi et al., 2004, 2005; Harangi and Lenkey, 2007; Seghedi and Downes, 2011; Harangi et al., 2015). The volcanism has been considered to have started with the eruption of silicic magmas (called the 'felsic group' in Seghedi and Downes, 2011), although borehole data in the interior of the Pannonian Basin indicate andesitic to dacitic precursor volcanic activity. This was followed by widespread calc-alkaline andesite-dacite-rhyolite, alkaline sodic and less voluminous potassic-ultrapotassic volcanism. The silicic volcanic activity was dominantly explosive with minor extrusive events. The cumulative thickness of the volcaniclastic deposits exceeds $1 \mathrm{~km}$ at the inner part of the Pannonian Basin (http://www.mfgi.hu/geobank). Most of the silicic volcanic products are covered entirely by young sediments due to the major subsidence after the continental rifting event and are only known from boreholes. However, the southern foreland of the Bükk Mts. (Bükkalja Volcanic Field, NE Hungary; Fig. 1) yields a unique exposure of the volcanic products. Therefore, our present summary is based primarily on the detailed studies of these rocks.

\subsection{The Bükkalja Volcanic Field (BVF)}

The Bükkalja Volcanic Field (BVF) is located in the Alcapa block, just north of the Mid-Hungarian Shear Zone (Fig. 1a). Well-preserved pyroclastic deposits occur in a $50 \mathrm{~km}$ long $10 \mathrm{~km}$ wide area (Fig. 1b) and provide an excellent opportunity to examine the nature of the Early to Mid-Miocene silicic volcanism of the Pannonian Basin. The volcanic succession contains mostly ignimbrites (both welded and unwelded) and pyroclastic fall layers (Pantó, 1963; Capaccioni et al., 1995; Szakács et al., 1998; Harangi et al., 2005; Less et al., 2005; Czuppon et al., 2012; Lukács et al., 2015). Previous K/Ar dating suggested that this volcanism occurred from 21 to $13 \mathrm{Ma}$ (Márton and Pécskay, 1998; Pécskay et al., 2006), whereas zircon U-Pb dating (Lukács et al., 2015) suggested a shorter duration of volcanism (until $\sim 14.1 \mathrm{Ma}$ ), prompting additional study to better constrain the period of magmatic activity in the area.

Two major syn-volcanic block-rotation events (Márton and Fodor, 1995; Márton and Pécskay, 1998; Márton et al., 2007) divide the volcanic suite into three parts. Stratigraphy of the volcanic deposits, and correlation to sedimentary formations, are difficult due to scattered outcrops and lack of associated datable sediments. Ignimbrites are mostly crystal-poor (typically 10-15 vol\% crystals), whereas the Bogács unit involves mostly crystal-rich (typically $30-40$ vol $\%$ crystals) volcanic products (Czuppon et al., 2012). The volcanic formations, cropping out in the BVF, continue southward in the basement (Petrik et al., 2016). They were penetrated by a large number of boreholes (Less et al., 2005; Lukács et al., 2010, 2015; http://www.mfgi.hu/geobank), many of them revealing several hundreds of metres (up to $800 \mathrm{~m}$ ) of continuous volcanic sequence.

The relative stratigraphy of the successive volcanic deposits in the BVF is summarized in Fig. 2 (representative photos of the main units are presented in ESM_2). It is based on new detailed volcanological, petrological and geochemical investigations, completed by former volcanological observations and interpretation of Szakács et al. (1998), Lukács et al. (2005, 2009, 2010) and Czuppon et al. (2012). In addition to the main distinguished ignimbrite units recognized in the field, we dated the stratigraphically oldest known pumice-bearing lapilli tuff revealed by a drilling core from the $240-243$ m section of Csv-2 (Cserépváralja-2) borehole (Fig. 1). This volcanic formation deposited just above the unconformity surface at $278 \mathrm{~m}$ covering a regionally distributed Oligo-Miocene fluvial clastic formation.

\section{Materials and methods}

Samples represent all the main volcanic formations of the BVF and cover the entire duration of the silicic volcanism in the region. Localities and descriptions of samples are summarized in ESM_1. Nineteen samples were dated by zircon U-Pb geochronology, and one sample (Harsány ignimbrite) was dated by ${ }^{40} \mathrm{Ar} /{ }^{39} \mathrm{Ar}$ dating of sanidine crystals. We also included the ages of 7 samples published by Lukács et al. (2015). Bulk rock geochemistry and in-situ zircon Hf isotopic analyses of 6 new samples are also reported. Details of analytical conditions and sample preparation are summarized in Lukács et al. (submitted) and in ESM_3.

Laser ablation analyses were conducted in two laboratories (Lukács et al., submitted) at ETH Zürich and in Göttingen University, which allowed us to test possible inter-laboratory differences using the same zircon aliquots and also to show the correlation effectiveness of LA-ICP-MS geochronology for relatively young (Miocene) samples. Single grain chemical abrasion ID-TIMS analyses of four samples were carried out on a Thermo-Scientific TRITONPLUS TIMS at ETH Zurich.

Fifteen sanidine crystals from a single pumice of Harsány ignimbrite unit (named TdA-P63) were dated by ${ }^{40} \mathrm{Ar} /{ }^{39} \mathrm{Ar}$ method in the New Mexico Geochronology Research Laboratory at New Mexico Tech, USA.

Chemical composition of pumices and bulk rocks was determined at the ACME Labs (Canada; http://www.acmelab.com/) using ICP-OES and ICP-MS technique for major-minor and trace elements, respectively. Internal standards and duplicate sample analysis by sessions were used to check the reliability of the results. In a few cases when no juvenile clasts of acceptable size were available, bulk pyroclastic rocks were used. Before analysis, these samples were carefully checked to avoid incorporation of lithic clasts. The analyzed samples are fresh showing apparently no or only minor secondary alteration.

In-situ Hf isotopic analysis was carried out over the course of two analytical sessions using a $193 \mathrm{~nm}$ ArF laser coupled to a Nu2 multi-collector inductively-coupled-plasma mass-spectrometer (MC-ICP-MS) at ETH Zürich.

\section{Results}

\subsection{Geochronology}

More than 1400 individual zircon spots from 19 samples were dated by LA-ICP-MS. The full dataset is presented in Lukács et al. (submitted) following the guidelines outlined by Horstwood et al. (2016). Because of the lower intensities of ${ }^{207} \mathrm{~Pb}$ and ${ }^{208} \mathrm{~Pb}$ and the larger influence from small amounts of common $\mathrm{Pb}$ on the ${ }^{207} \mathrm{~Pb} /{ }^{235} \mathrm{U}$ and ${ }^{208} \mathrm{~Pb} /{ }^{232} \mathrm{Th}$ ages, we consider only ${ }^{206} \mathrm{~Pb} /{ }^{238} \mathrm{U}$ ages for interpretation, and we filtered out data with $>10 \%$ discordance (Table 1 ). We analyzed the samples in 20 sessions along with common zircon reference materials (GJ-1, Plešovice, 91,500, Temora2, OD-3, LG_0302, AUSZ7-1, AUSZ7-5; for references see Lukács et al., submitted). The average precision of the reference materials ranged from $0.6 \%$ to $3 \%$ (2se). Validation reference materials were used to correct the matrix-dependent age offsets (Marillo-Sialer et al., 2014; details are in Sliwinski et al., 2017 and in Lukács et al., submitted). Dates on the same zircon aliquots from the two laboraties gave concordant age results.

Most ${ }^{206} \mathrm{~Pb} /{ }^{238} \mathrm{U}$ dates are between $\sim 20$ and $\sim 14 \mathrm{Ma}$, with very few xenocrystic cores (EG1: 122.9 $\pm 10 \mathrm{Ma} ; 396.5 \pm 5.3 \mathrm{Ma} ; \mathrm{EG} 2$ : $22.4 \pm 0.7 \mathrm{Ma}$; CsTb1: $56.5 \pm 11.6 \mathrm{Ma} ; \mathrm{CSO} 1: 243.8 \pm 18 \mathrm{Ma} ; \mathrm{SZOM}$ : $887.9 \pm 8.2 \mathrm{Ma}$; Td-Fi: $392.7 \pm 8.1 \mathrm{Ma}$ ). Uncertainties of individual zircon analyses are given as 2 se and are usually $1-3.5 \%$ relative standard 


\begin{tabular}{|c|c|c|c|c|c|c|}
\hline Unit & Age (Ma) & $\begin{array}{l}\text { Max. obser } \\
\text { thickness }\end{array}$ & Volcanology & Petrography & Geochemistry & Lithology \\
\hline $\begin{array}{l}\text { Harsány } \\
\text { ignimbrite }\end{array}$ & $\begin{array}{l}14.358 \\
\pm 0.015\end{array}$ & $40 \mathrm{~m}$ & $\begin{array}{l}\text { pumiceous block-bearing } \\
\text { lapilli tuff - unwelded } \\
\text { ignimbrite }\end{array}$ & $\begin{array}{l}\text { Plagioclase, quartz, } \\
\text { biotite, sanidine }\end{array}$ & $\begin{array}{l}\text { bimodal pumices: } \\
\text { high-Si rhyolite } \\
\text { pumices "Sr/ }{ }^{m} \mathrm{Sr} r_{i} \sim \\
0.7073 \text { and } 0.7079 \text {; } \\
\text { zr \& } \mathrm{Hf} \sim-1.9\end{array}$ & i \\
\hline Tibolddaróc & $14.7 \pm 0.2$ & $1.5 \mathrm{~m}$ & $\begin{array}{l}\text { fine lapilli tuff and tuff } \\
\text { formed by pyroclastic flow } \\
\text { and fall }\end{array}$ & $\begin{array}{l}\text { Plagioclase, quartz, } \\
\text { biotite, sanidine }\end{array}$ & rhyolite & \\
\hline $\begin{array}{l}\text { Demjén } \\
\text { ignimbrite }\end{array}$ & $\begin{array}{l}14.880 \pm \\
0.014\end{array}$ & $50 \mathrm{~m}$ & $\begin{array}{l}\text { pumiceous block-bearing } \\
\text { lapilli tuff \& tuff - unwelded } \\
\text { to slightly welded } \\
\text { ignimbrite, ash-flow and } \\
\text { occasional accretionary } \\
\text { lapilli bearing phreato- } \\
\text { magmatic/magmatic fall } \\
\text { deposit }\end{array}$ & $\begin{array}{l}\text { Plagioclase, biotite, } \\
\text { amphibole, (quartz) }\end{array}$ & $\begin{array}{c}\text { dacite-rhyodacite, } \\
\text { pumice }{ }^{n} \mathrm{Sr} /{ }^{\prime \prime} \mathrm{Sr} \sim \\
0.7073 \\
\text { zr } \& \mathrm{Hf} \sim+0.3\end{array}$ & $\begin{array}{c}0 \\
0 \\
0 \\
0 \\
0 \\
0 \\
0 \\
0\end{array}$ \\
\hline Td-J & $16.2 \pm 0.3$ & $0.5 \mathrm{~m}$ & $\begin{array}{l}\text { fine tuff formed by } \\
\text { pyroclastic fall }\end{array}$ & $\begin{array}{l}\text { Plagioclase, quartz, } \\
\text { biotite }\end{array}$ & $\begin{array}{l}\text { rhyolite } \\
\mathrm{zr} \& \mathrm{Hf} \sim-0.9\end{array}$ & \\
\hline$T d-L$ & $16.7 \pm 0.3$ & $0.4 \mathrm{~m}$ & $\begin{array}{l}\text { accretionary lapilli-bearing } \\
\text { tuff - phreatomagmatic/ } \\
\text { magmatic fall deposit }\end{array}$ & $\begin{array}{l}\text { Plagioclase, quartz, } \\
\text { biotite }\end{array}$ & rhyolite & $\because \because: 8$ \\
\hline Bogács & $\begin{array}{c}16.816 \pm \\
0.059\end{array}$ & $70 \mathrm{~m}$ & $\begin{array}{l}\text { it consists of two subunits - } \\
\text { (1) a lower unwelded } \\
\text { followed by fiamme-bearing } \\
\text { welded ignimbrite overlain } \\
\text { by (2) mixed scoria-pumice } \\
\text { bearing pyroclastic flow } \\
\text { deposit with intercalated } \\
\text { fall layer }\end{array}$ & $\begin{array}{l}\text { Plagioclase, biotite, } \\
\text { orthopyroxene, quartz, } \\
\text { amphibole }\end{array}$ & $\begin{array}{l}\text { mixed clasts: } \\
\text { andesite-dacite } \\
\text { pumice }{ }^{8} \mathrm{Sr} /{ }^{p 1} \mathrm{Sr} \sim \\
0.7113 \\
\mathrm{zr} \& \mathrm{Hf} \sim-8.95\end{array}$ & \\
\hline $\begin{array}{l}\text { Mangó } \\
\text { ignimbrite }\end{array}$ & $\begin{array}{c}17.055 \pm \\
0.024\end{array}$ & $250 \mathrm{~m}$ & $\begin{array}{l}\text { pumiceous block-bearing } \\
\text { lapilli tuff \& tuff - unwelded } \\
\text { ignimbrite occasionally } \\
\text { interbedded with fiamme- } \\
\text { bearing welded ignimbrite; } \\
\text { lapilli tuff and tuff often } \\
\text { with accretionary lapilli - } \\
\text { phreatomagmatic/ } \\
\text { magmatic flow/surge } \\
\text { and fall deposits }\end{array}$ & $\begin{array}{l}\text { Plagioclase, quartz, } \\
\text { biotite, (sanidine) }\end{array}$ & $\begin{array}{l}\text { rhyolite, } \\
\text { pumice }{ }^{\text {" }} \mathrm{Sr} / \mathrm{sr} \sim \\
0.7097 \\
\mathrm{zr} \& \mathrm{Hf} \sim-7.7\end{array}$ & 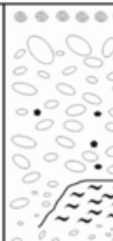 \\
\hline $\begin{array}{l}\text { Eger } \\
\text { ignimbrite }\end{array}$ & $17.5 \pm 0.3$ & $30 \mathrm{~m}$ & $\begin{array}{l}\text { pumiceous block-bearing } \\
\text { lapilli tuff \& tuff - unwelded } \\
\text { ignimbrite }\end{array}$ & $\begin{array}{l}\text { Plagioclase, quartz, } \\
\text { biotite }\end{array}$ & $\begin{array}{l}\text { rhyolite, } \\
\text { pumice }{ }^{s} \mathrm{Sr} / \mathrm{sr} \sim \\
0.7090\end{array}$ & 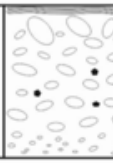 \\
\hline Csv-2 & $18.2 \pm 0.3$ & $40 \mathrm{~m}$ & $\begin{array}{l}\text { pumiceous lapilli tuff - } \\
\text { unwelded ignimbrite }\end{array}$ & $\begin{array}{l}\text { Plagioclase, quartz, } \\
\text { biotite, (sanidine) }\end{array}$ & $\begin{array}{l}\text { rhyolite, } \\
\mathrm{zr} \& \mathrm{Hf} \sim-7.8\end{array}$ & $\mid \begin{array}{ll}0 & 0 \\
0 & 0 \\
0 & 0\end{array}$ \\
\hline
\end{tabular}

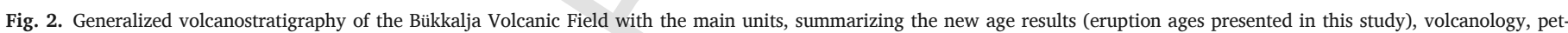

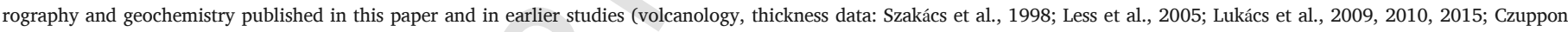

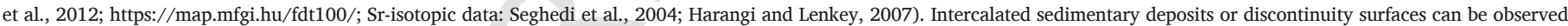

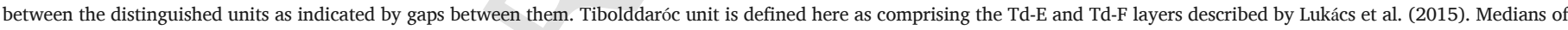
epsilon Hf values are given for the units, where available.

error for the ETH Zürich analyses (without external, systematic uncertainties) and 3-8.7\% for those from Göttingen University.

Assuming that uncertainties are accurately quantified, the U-Pb dates provide the timing of zircon crystallization. However, in order to deduce eruption ages from these dates it is necessary for zircon to crystallize as a late, autocrystic phase close to the timing of eruption (Miller et al., 2007). For most samples the LA-ICP-MS analyses yield a relatively large scatter of U-Pb zircon dates and high MSWD values suggesting the possible incorporation of xenocrystic or antecrystic (i.e. crystallized from an earlier pulse of cogenetic magma; Miller et al., 2007) zircon grains in the weighted mean calculation. Lukács et al. (2015) discussed this issue and other possible factors causing large distribution of U-Pb zircon dates in single samples and suggested that, in such cases, the youngest age population could be used to constrain the eruption age. A previous study on the volcanic rocks from the Pannonian Basin has demonstrated that post-crystallization radiogenic $\mathrm{Pb}$-loss should not affect the results significantly (Lukács et al., 2015). Three samples (Bogács unit, Table 1) interpreted in this study were also chemically abraded before LA-ICP-MS analyses (Lukács et al., submitted).

In order to accurately constrain the eruption age, we applied the following methodology. Starting with the youngest date, we included all the successive zircon dates until the MSWD value suggested a coherent isochron population. The eruption age was calculated by the weighted mean of this spot date population and is termed as the "youngest isochronous age" in Table 1. Uncertainties on the interpreted eruption ages are propagated from population mean age uncertainties and 1.5\% external systematic errors including several sources of errors, detailed in Lukács et al. (2015), and systematic errors on the Th-disequilibrium correction and on the correction of alpha dose-dependent age offsets (details in Sliwinski et al., 2017). Samples of different localities were correlated based on their youngest isochronous age (and geochemical constrains, see below and Lukács et al., 2015) and grouped into eruption units (Fig. 2 and Table 1).

We performed single grain CA-ID-TIMS dating on four samples from the main eruption units, i.e. Harsány, Demjén, Bogács and Mangó units 
Table 1

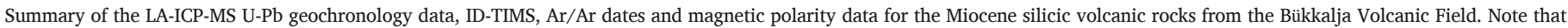
LA-ICP-MS ages can be compared with other geochronological results (i.e. ID-TIMS and Ar-Ar) when considering external error included in the uncertainty.

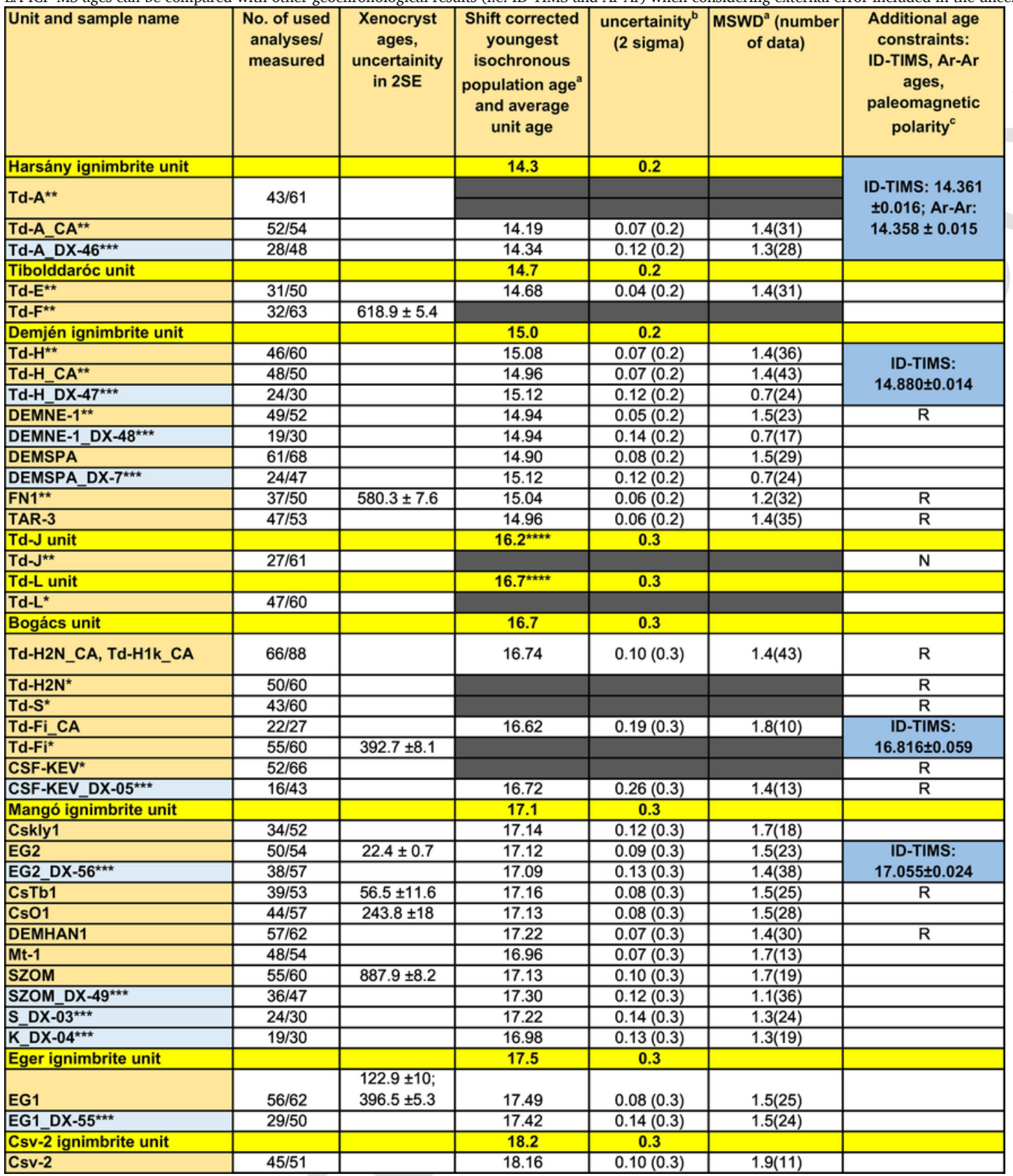

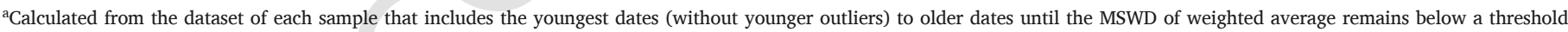
value indicating isochronous age (Wendt and Carl, 1991).

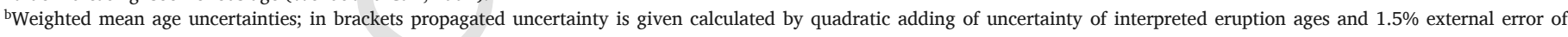
LA-ICP-MS measurements.

${ }^{\mathrm{c}} \mathrm{R}$ = reverse, $\mathrm{N}$ = normal polarity; palaeomagnetic data from Márton and Pécskay, 1998 and Márton et al., 2007.

*Without shift correction.

**Measured data and shift uncorrected interpretation ages from Lukács et al., 2015;

****Results of LA-ICP-MS analyses of Göttingen University.

****Calculated age using the shift correction degree inferred from samples of the same session where shift correction was possible.

to test the accuracy of the eruption ages obtained from the zircon LA-ICP-MS dates. Using the same separated zircon grain fraction from Td-A (Harsány ignimbrite unit), Td-H (Demjén ignimbrite unit), Td-Fi1 (Bogács unit) and EG2 (Mangó ignimbrite unit) samples used for the LA-ICP-MS analyses, we performed a total of 23 individual grain CA-ID-TIMS analyses (Fig. 3). We also include the previously published
CA-ID-TIMS dates from the Harsány ignimbrite unit (Lukács et al., 2015).

Eleven ID-TIMS compiled zircon dates from the Harsány ignimbrite exhibit a range in ${ }^{206} \mathrm{~Pb} /{ }^{238} \mathrm{U}$ dates from $14.424 \pm 0.020 \mathrm{Ma}$ to $14.361 \pm 0.016 \mathrm{Ma}$. The six ${ }^{206} \mathrm{~Pb} /{ }^{238} \mathrm{U}$ ID-TIMS dates from the Demjén ignimbrite range between $15.119 \pm 0.020 \mathrm{Ma}$ and $14.880 \pm 0.014 \mathrm{Ma}$, 

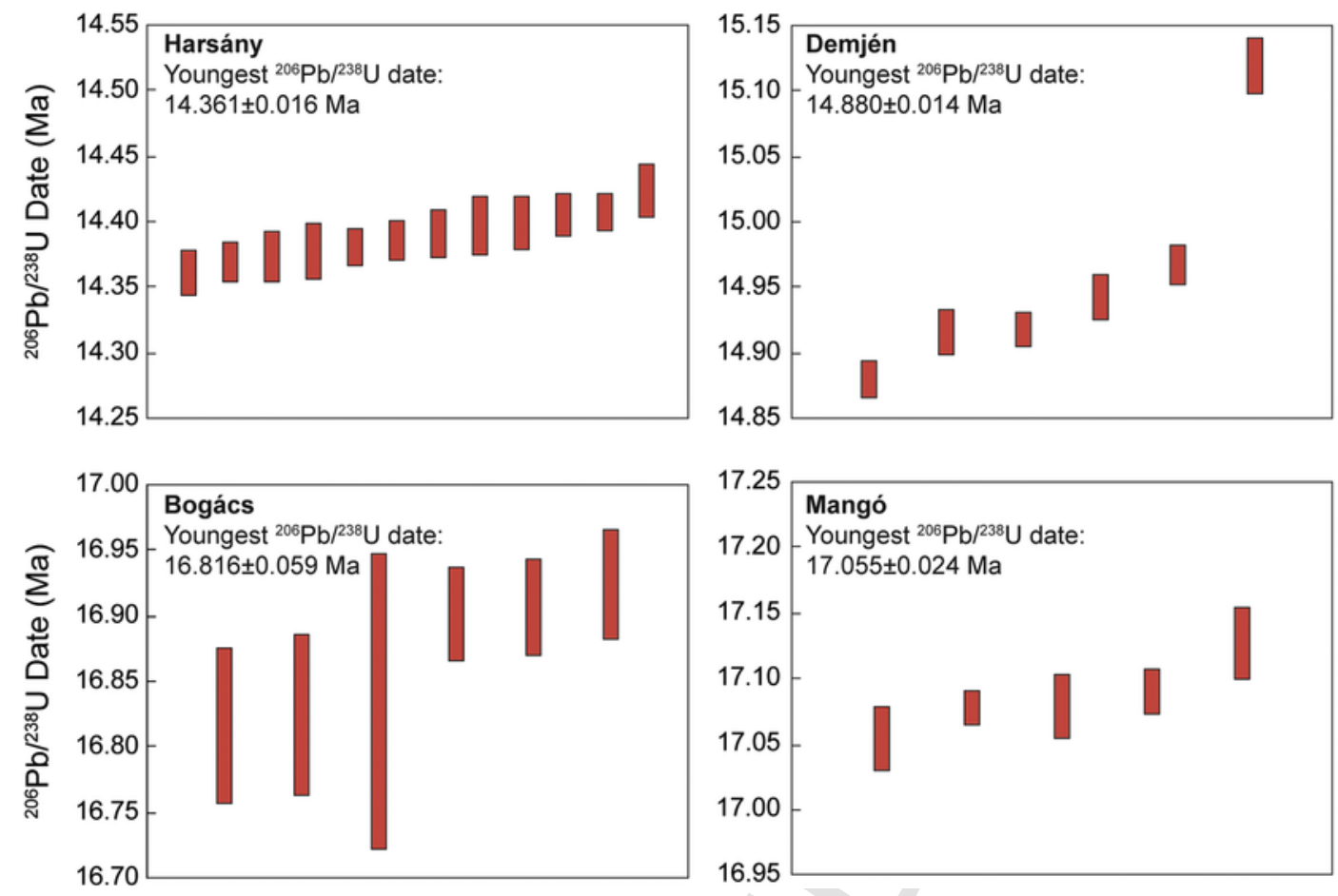

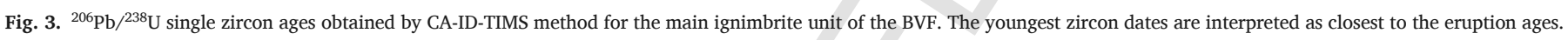

the six dates of the Bogács unit scatter between $16.923 \pm 0.041 \mathrm{Ma}$ and $16.816 \pm 0.059 \mathrm{Ma}$, while the five EG-2 sample dates representing the Mangó ignimbrite fall between $17.128 \pm 0.027 \mathrm{Ma}$ and $17.055 \pm 0.024 \mathrm{Ma}$ (Fig. 3). Since the range in zircon dates point towards protracted zircon crystallization in the magma chamber of between $63 \pm 26 \mathrm{kyr}$ and $239 \pm 24 \mathrm{kyr}$ for the respective samples, we use the youngest grains from a sample as a proxy for the "eruption" age (e.g., Schoene et al., 2010).

Fourteen of fifteen sanidine single-crystal laser-fusion dates from a single pumice of the Harsány ignimbrite unit (TDA-P63) range from $14.408 \pm 0.004$ to $14.286 \pm 0.007 \mathrm{Ma}$ (see ESM_2). One crystal yielded a much older age of $33.817 \pm 0.008 \mathrm{Ma}$. One-sigma uncertainties for most analyses are $<10 \mathrm{ka}$. A total of six dates were excluded from the age calculation because they yielded either low radiogenic argon $(<95 \%)$, significantly different $\mathrm{K} / \mathrm{Ca}$ values compared to the main population, or anomalously older ages. The remaining nine analyses were used to calculate a weighted-mean age of $14.358 \pm 0.015 \mathrm{Ma}(2 \sigma$ error) and interpreted as eruption age.

\subsection{Geochemistry}

New bulk rock compositional data of juvenile clasts (pumices and scoriae) were combined with literature data (Seghedi et al., 2004; Harangi and Lenkey, 2007; Lukács et al., 2005; Lukács et al., 2009; Czuppon et al., 2012) to cover the full spectrum of the silicic volcanism. Pumices are dominantly high- $\mathrm{K}$ rhyolites $\left(\mathrm{K}_{2} \mathrm{O} / \mathrm{Na}_{2} \mathrm{O}>2 ; \mathrm{K}_{2} \mathrm{O}>4 \mathrm{wt} \%\right)$, only those from the Demjén ignimbrite are slightly less silicic (rhyodacitic composition; Fig. 4a). The Harsány ignimbrite has a bimodal pumice population, where the dominant pumices are high-K rhyolites $\left(\mathrm{K}_{2} \mathrm{O}=5-5.2 \mathrm{wt} \%\right)$, while the others are less potassic $\left(\mathrm{K}_{2} \mathrm{O}=3.5-4.9 \mathrm{wt} \%\right)$ rhyolites (Lukács et al., 2009). In the Bogács unit, juvenile clasts (black and grey scoriae clasts, pumices, fiamme) have very different compositions (mostly andesitic and dacitic; $\mathrm{SiO}_{2}$ ranges from 59 to $69 \mathrm{wt} \%$ ) and they overlap with the compositional spectrum of the clasts found as lithics in the rhyolitic ignimbrites (Lukács et al., 2005; Harangi and Lenkey, 2007). This wide geochemical variation for the Bogács unit was explained by mingling of crystal mush and melts prior to and during the eruptive episodes (Czuppon et al., 2012).

Trace element compositions of the juvenile clasts are variable and mostly appear to be characteristic of the individual eruptive unit (Fig. 4b, ESM_1). The Eger and Mangó ignimbrites have different trace element patterns, where the Eger ignimbrite shows some similarities to the younger Demjén ignimbrite. The Demjén ignimbrite has a well-characterized trace element pattern with depleted heavy rare earth elements and no pronounced negative Eu-anomaly (Eu/Eu* = 0.8-0.9; Fig. 4c). In contrast, the Harsány ignimbrite has a clear negative Eu-anomaly (Eu/ $\mathrm{Eu}^{*}=0.3-0.4$ ), is enriched in heavy REE and has lower $\mathrm{Zr}$ and $\mathrm{Hf}$ and higher Ba contents ( $\mathrm{Zr}<110$ ppm; $\mathrm{Hf}<3.5 \mathrm{ppm}$; Ba $>800$ ppm; ESM_1). This compositional difference between the Harsány and Demjén units is reflected also in the trace element content of the zircons (Lukács et al., 2015). The andesitic to dacitic clasts of the Bogács unit also have distinctive major and trace element compositional features (ESM_1). Thus, trace element fingerprints of the ignimbrite units can be effectively used for discrimination purposes, as can their glass and mineral chemical characters (Harangi et al., 2005; Lukács et al., 2015).

The Sr and Nd isotopic compositions of the pumices also show distinct values. Pumices from the younger ignimbrites formed after eruption of the Bogács unit have typically lower ${ }^{87} \mathrm{Sr} /{ }^{86} \mathrm{Sr}_{\mathrm{i}}(0.7073-0.7079)$ and higher ${ }^{143} \mathrm{Nd} /{ }^{144} \mathrm{Nd}(0.51244-0.51245)$ isotope ratios, overlapping with isotopic ratios from the andesitic to dacitic lithic clasts of the older ignimbrites (Harangi and Lenkey, 2007) and the Mid-Miocene calc-alkaline andesites of the Northern Pannonian Basin (Harangi et al., 2007).

Hafnium isotopic compositions of zircons from 6 samples, covering the entire duration of the BVF volcanism, range between $\varepsilon \mathrm{Hf}=2.67 \pm 1.83$ and $-13.28 \pm 1.69$ (2se; ESM_1) and, as for the Sr and $\mathrm{Nd}$ isotopes, show systematic temporal variations. The lowest $\varepsilon \mathrm{Hf}$ 

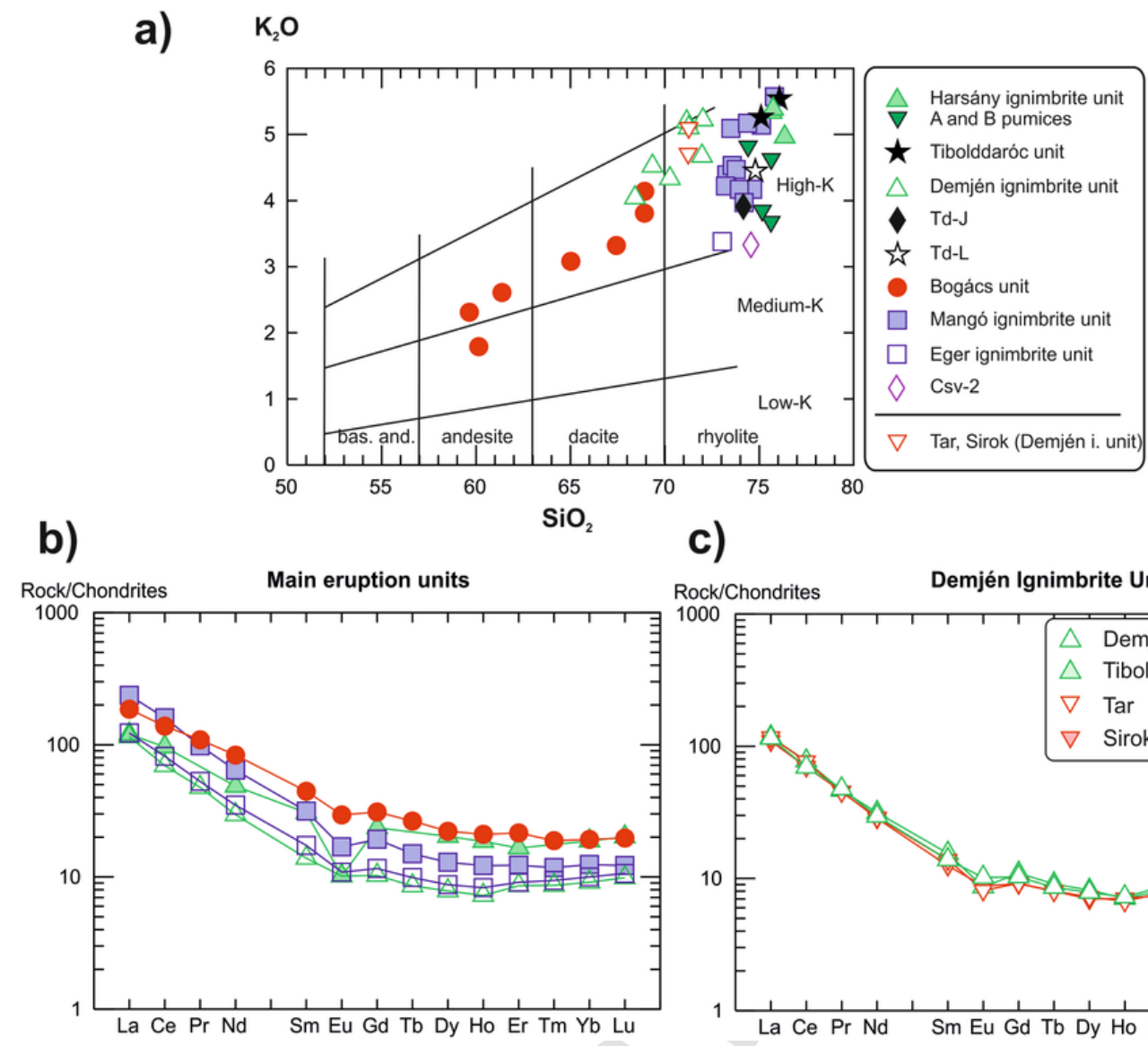

Demjén Ignimbrite Unit

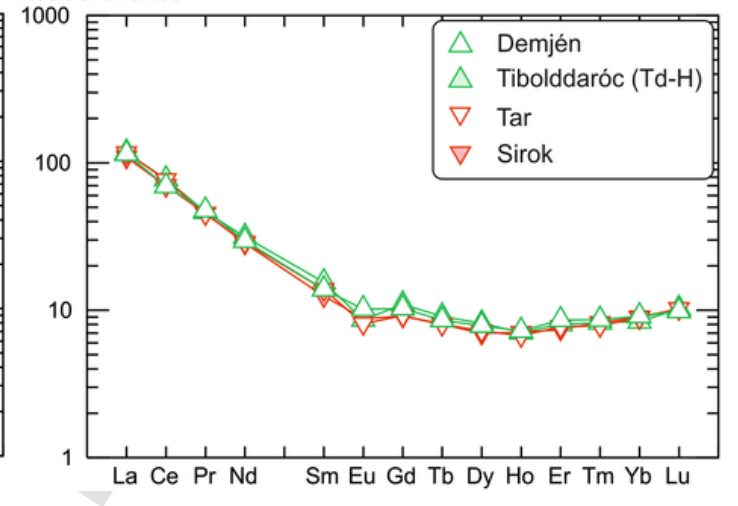

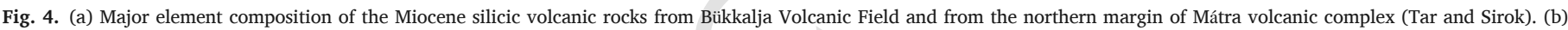

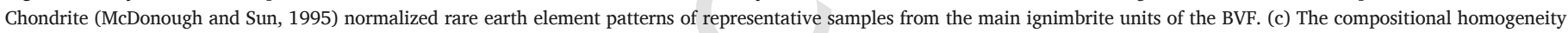

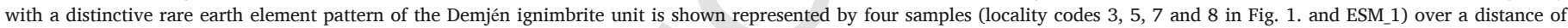
$65 \mathrm{~km}$.

values are from the Bogács unit (CSF-KEV; data median:-8.95). In contrast to the larger variation shown by the Td-J and CSF-KEV zircons ( $\varepsilon H f:-5.36$ to 2.67 and -13.28 to -6.35 , respectively), the other samples have relative homogeneous $\varepsilon \mathrm{Hf}$ compositions. The CSF-KEV rock sample has mixed/mingled juvenile clast population (i.e. scoriae and pumices; Czuppon et al., 2012) suggesting different magmas involved in their crystallization history. The zircon grains separated from this rock show large inter- and intra-grain variations in $\mathrm{U}$ concentration and show relatively large Hf-isotopic variation.

\section{Discussion}

\subsection{Eruption chronology}

Based on the interpreted eruption ages, 8 distinct eruption phases were distinguished within a time period from 18.2 Ma to $14.4 \mathrm{Ma}$ (Table 1, Figs. 5-7). Accuracy of the determined eruption ages is supported by the concordant results obtained from two different laboratories, using different analytical and data-reduction procedures (Lukács et al., submitted) as well as the concordant ID-TIMS zircon and Ar-Ar sanidine ages. These latter ages support our interpretation for the zircon LA-ICP-MS dates, i.e. choosing the youngest isochronous age population that approaches the eruption ages (Figs. 5 and 6). Thus, the silicic volcanism involved more eruption phases and was significantly shorter than inferred from the previous K/Ar dates (Márton and Pécskay, 1998). Our results demonstrate that there were two intense eruptive periods with more closely packed eruption events (from 17.5 to $16.2 \mathrm{Ma}$ and from 14.9 to $14.4 \mathrm{Ma}$, respectively) separated by a relatively long ( $1.3 \pm 0.3 \mathrm{Myr}$ ) hiatus in volcanism (Fig. 7).

The initiation of the silicic volcanism is constrained by a drill-core (Csv-2, see Fig. 1) sample from a lapilli tuff, which directly overlies the Early Miocene bedrock. This tuff is comformably overlain by the younger BVF pyroclastic rocks (http://www.mfgi.hu/geobank) and yields an eruption age of $18.2 \pm 0.3 \mathrm{Ma}$ (Fig. 5a). It was followed by the resolvably younger Eger ignimbrite $(17.5 \pm 0.3 \mathrm{Ma}$; Figs. 2 and $5 \mathrm{a})$, which was deposited on the palaeosurface of Early Miocene clastic sedimentary formations as shown by Szakács et al. (1998) in a few outcrops around Eger.

The most widespread rhyolitic pyroclastic products are from the Mangó ignimbrite unit, with an interpreted eruption age of $17.055 \pm 0.024 \mathrm{Ma}$ and $17.1 \pm 0.3 \mathrm{Ma}$ based on the ID-TIMS and LA-ICP-MS measurements, respectively (Figs. 3 and 5a). These ages, together with the reverse palaeomagnetic polarity of these rocks (Márton et al., 2007) suggests they are part of the C5Cr subchron (Gee and Kent, 2007) between 16.726 and $17.277 \mathrm{Ma}$ (Fig. 7). Correlation of the rocks from the different localities of Mangó ignimbrite is established based on the interpreted LA-ICP-MS eruption ages (Fig. 5b) and similar bulk rock geochemistry, but note that the eruption unit may contain several eruption events that are not temporally resolved in this study.

Eruption ages of Eger and Mangó ignimbrite units (17.5 to 17.1 Ma) are significantly younger than those previously determined by K/Ar dating on the same rocks (21.0 to $18.5 \mathrm{Ma}$; Márton and Pécskay, 1998). 

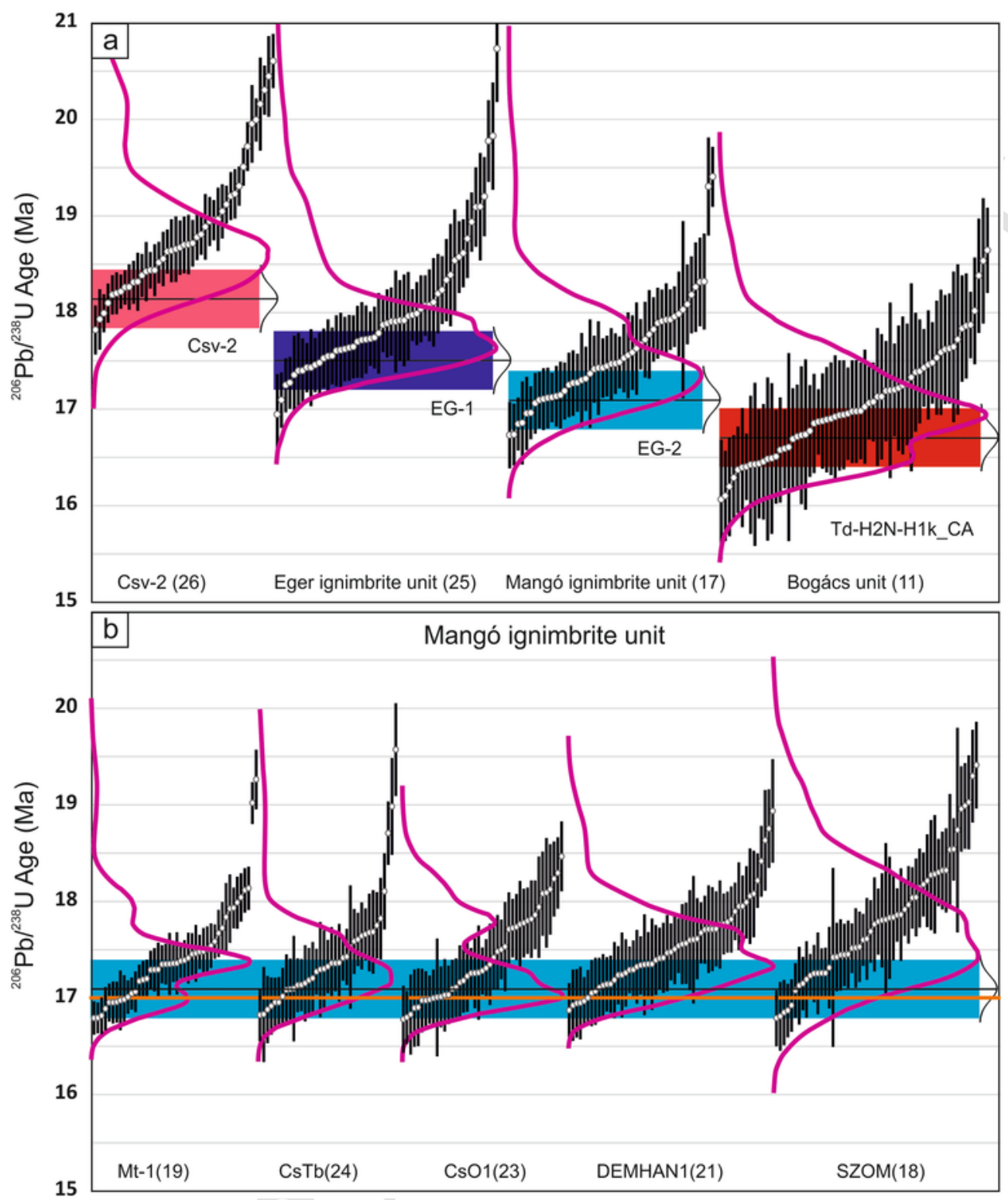

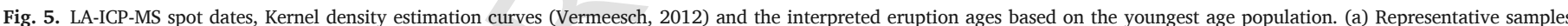

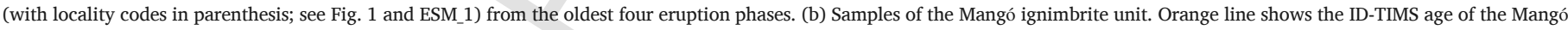
ignimbrite. Coloured bars and the Gaussian curves represent the interpreted eruption ages of units with their uncertainty ( 2 sigma).

However, these latter ages were obtained either from bulk rock samples or biotites, which often show alteration or have excess Ar, which could obscure the K/Ar results (Hora et al., 2007). The Mangó ignimbrite eruption age can be correlated with the age of ignimbrites in Northern Hungary (Ar-Ar age of Ipolytarnóc is $17.02 \pm 0.14 \mathrm{Ma}$ based on Pálfy et al., 2007, which is recalculated to $17.13 \pm 0.14 \mathrm{Ma}$ using new decay constant proposed by Kuiper et al., 2008) that are stratigraphically distinguished as "Lower Rhyolite Tuff Formation" in the Hungarian lithostratigraphy. This has been considered as a stratigraphically important regional key-horizon in the Pannonian Basin at the Eggenburgian-Ottnangian boundary (formerly determined using K/Ar method as $19.6 \pm 1.4 \mathrm{Ma}$; Hámor et al., 1980). However, the new zircon $\mathrm{U}-\mathrm{Pb}$ geochronological data set shows that it has a much younger age $(17.1 \pm 0.3 \mathrm{Ma})$.

The Bogács unit is a well-recognizable volcanic horizon in the BVF (Fig. 1) based on its volcanological and petrologic features described in detail by Czuppon et al. (2012). Juvenile samples (fiamme, scoria and pumice) from its two subunits and the overlying accretionary lapilli-bearing Td-L unit (Fig. 2) give concordant zircon LA-ICP-MS $\mathrm{U}-\mathrm{Pb}$ dates and yield an interpreted eruption age of $16.7 \pm 0.3 \mathrm{Ma}$ (Fig. $5 a)$. The ID-TIMS eruption age of $16.816 \pm 0.059 \mathrm{Ma}$ (Fig. 3) for the upper subunit sample of Bogács unit is in agreement with the interpreted LA-ICP-MS age. The reverse palaeomagnetic polarity (Márton et al., 2007) of this unit indicates its formation (for both subunits) between the C5Cn.3n and C5Dn subchrons (C5Cr; 16.726-17.277Ma; Fig. 7). A break in the volcanism between the Mangó ignimbrite and Bogács unit is supported by recognition of intercalated fluvioclastic deposits by Szakács et al. (1998), as well as the distinct palaeomagnetic rotation data (Márton and Pécskay, 1998; Márton et al., 2007). Our new eruption ages therefore constrain the timing of the first major, $40-50^{\circ}$ counterclockwise rotation event (between $17.055 \pm 0.024$ and $16.816 \pm 0.059 \mathrm{Ma}$; Fig. 7), significantly later than previously suggested (18.5-17.5 Ma; Márton et al., 2007). 


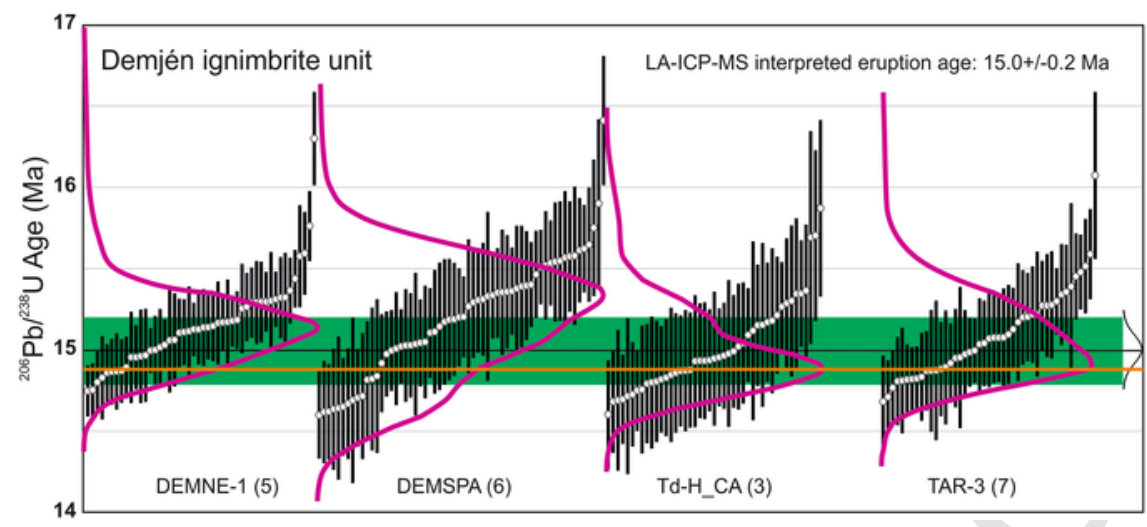

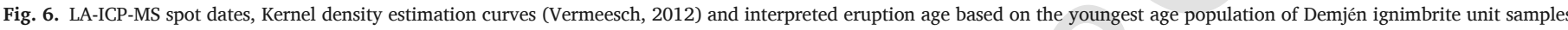

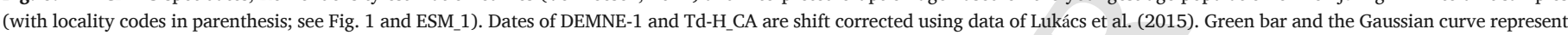

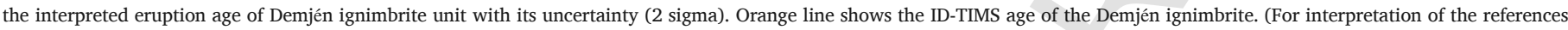
to colour in this figure legend, the reader is referred to the web version of this article.)

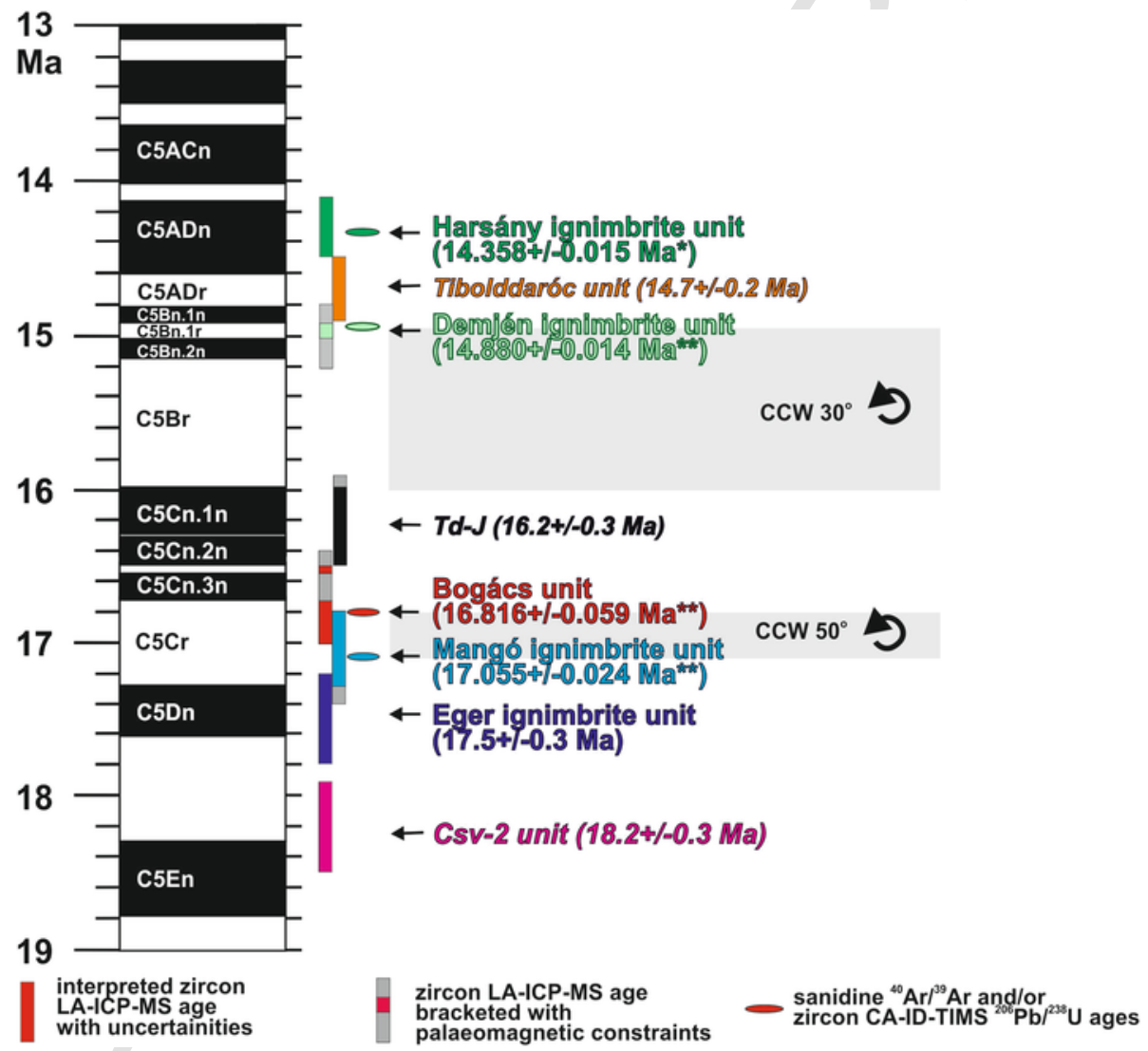

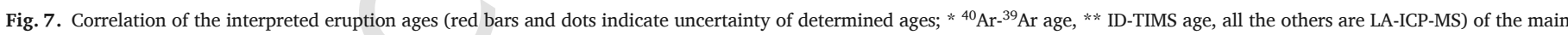

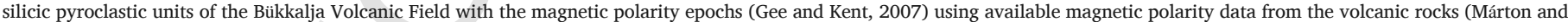

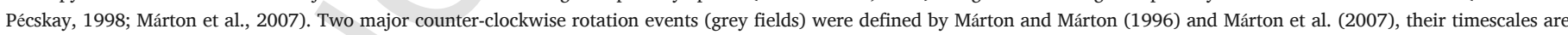
refined here based on the new eruption ages. (For interpretation of the references to colour in this figure legend, the reader is referred to the web version of this article.)

Zircon U-Pb-based eruption chronology of the subsequent volcanism was given by Lukács et al. (2015) and their proposed ages are slightly refined here: we conducted dose corrections on the formerly published ages and added additional geochronological results in order to more accurately evaluate the dates (Table 1, Figs. 6 and 7). Following the formation of the Td-J lapilli tuff bed at $16.2 \pm 0.3 \mathrm{Ma}$, there was a relatively long $(1.3 \pm 0.3 \mathrm{Myr})$ pause in silicic volcanism. Volcanism resumed with eruption of Demjén ignimbrite at $14.880 \pm 0.014$ Ma (ID-TIMS; Fig. 3) confirming the interpreted eruption age of $15.0 \pm 0.2 \mathrm{Ma}$ obtained from the LA-ICP-MS zircon dates (Fig. 6; Table 1). Note that we cannot exclude the possibility of several, closely occurred eruption events, which are unresolvable with the LA-ICP-MS method, but all of these volcanic products have strikingly similar trace element patterns (Fig. 4c). This age together with the reverse palaeomagnetic polarity of the Demjén ignimbrite (Márton et al., 2007) and indicates that it falls within the short C5Bn.1r subchron (14.888-15.034Ma; Fig. 7). The eruption age of the subsequent Tibolddaróc unit (Td-E and Td-F units in Lukács et al., 2015) is modified to $14.7 \pm 0.2 \mathrm{Ma}$, based on the shift- 
corrected data. The youngest CA-ID-TIMS zircon age $(14.361 \pm 0.016 \mathrm{Ma})$ and new Ar-Ar age on sanidine crystals $(14.358 \pm 0.015 \mathrm{Ma})$ for the Harsány ignimbrite overlap within uncertainty and also with the shift-corrected eruption age determined from the LA-ICP-MS zircon dates $(14.3 \pm 0.2 \mathrm{Ma}$; Fig. 7). This represents the age of the youngest eruption phase of the silicic volcanic suite of the BVF (Lukács et al., 2015).

\subsection{Implications for eruptive volumes}

Individual ignimbrite deposits show several tens of metres thickness in many locations of the BVF, while the cumulative thickness of the pyroclastic deposits exceeds $1 \mathrm{~km}$ in some boreholes. This suggests that large volume of magmas erupted in the Pannonian Basin during the Miocene. Determination of the exact volume of the erupted tephras is difficult, because of subsequent erosion, subsidence, sporadic occurrences and the lack of precise correlation of the volcanic products. However, our new geochronological and geochemical data together with drill core descriptions can provide a more robust estimate for the cumulative eruptive volume.

Based on the similarity in the trace element content of the glass shards, the ca. $35 \mathrm{~m}$ thick unwelded silicic ignimbrite at Tar (NW Mátra Mts.; Code No. 7 in Fig. 1) could be closely correlated with the Demjén ignimbrite, found $>40 \mathrm{~km}$ away (Harangi et al., 2005). Pumices from these two ignimbrite occurrences show the same trace element pattern characterized by depleted middle and heavy rare earth elements, unique within the entire silicic volcanism of the BVF (Fig. 4c). The overlapping zircon $\mathrm{U}-\mathrm{Pb}$ dates of the ignimbrite samples from Tar and Demjén (Fig. 6), confirms that they could belong to the same eruption event that formed the Demjén ignimbrite unit. Northeast of Mátra, another thick ignimbrite is found at Sirok (Code No. 8 in Fig. 1). Trace element composition of its pumices is very similar with those of the Demjén ignimbrite (Fig. 4c). Thus, a continuous belt of rhyodacitic pyroclastic rocks, belonging to the same eruption unit can be inferred around the northern part of the Mátra, with up to 30-50 m thicknesses at certain locations over several 10's of $\mathrm{km}$. This implies a large volume eruption event. Since these rocks stratigraphically underlie the oldest lava rocks of the Mátra (where no accurate age dating is available), development of this volcanic complex should have occurred after $15 \mathrm{Ma}$.

Pantó (1965) and Ravasz (1987) provided areal distribution maps for the silicic volcanic formations in the Pannonian Basin based on data from several hundred boreholes. We have used an updated database (http://www.mfgi.hu/geobank) based on detailed descriptions of $>1800$ boreholes covering the entire Pannonian Basin, to infer the minimum volume of the eruptive material. Using the collective thickness data for all the Early to Mid-Miocene pyroclastic deposits, we obtained an average thickness of $88 \mathrm{~m}$ over an area of $50,000 \mathrm{~km}^{2}$ (Fig. 1a). This means ca. $4400 \mathrm{~km}^{3}$ volcanic material most probably corresponding to the determined $18.2-14.4 \mathrm{Ma}$ time span. This considerable volume is comparable to the secondary to tertiary magmatic pulses of ignimbrite flare-up episodes (de Silva et al., 2015; Gravley et al., 2016).

In the Pannonian Basin, the largest extent is shown by the so-called Middle Dacite Tuff horizon (Ravasz, 1987), which could be (in most localities) equivalent to the $14.880 \pm 0.014$ Ma Demjén ignimbrite, defined in this study. This is a stratigraphic key-layer in the Pannonian Basin that covers at least $30,000 \mathrm{~km}^{2}$ with up to $25-200 \mathrm{~m}$ thickness in certain places. This would require a minimum of several $100 \mathrm{~km}^{3}$ of volcanic material, whereas only around the Mátra-Bükk area (Fig. 1), the minimum exposed volume of the Demjén ignimbrite is calculated to be $12-15 \mathrm{~km}^{3}$. Such large amount of expelled volcanic material re- quires a caldera-forming eruption (CFE). However a caldera-like structure has not been recognized to date, either on the surface, or in the basement rocks. Based on the areal distribution and thickness data of the volcanic products, we tentatively suggest that the source of this large eruption could have been the location where the subsequent andesitic Mátra volcanic complex developed (Fig. 1b).

The older ignimbrite units, here referred to as the Eger and Mangó ignimbrites, belong to the Lower Rhyolite Tuff horizon, which is another stratigraphic key-layer in the Pannonian Basin. These volcanic deposits also have a large areal extent, up to $50,000 \mathrm{~km}^{2}$ and $80-450 \mathrm{~m}$ thickness at several locations. Lukács et al. (2010) described unwelded and welded ignimbrites belonging to this unit with $>250 \mathrm{~m}$ thickness in a borehole east of the BVF. Based on the borehole data, we infer that these two eruptions could also have yielded cumulative volume of several 100 's $\mathrm{km}^{3}$ of tephra.

\subsection{Distal impact of the BVF volcanism and its role in the Paratethys stratigraphy}

Large volume volcanism can have significant impacts over wide areas (Self, 2006). During the Miocene, explosive volcanic eruptions of silicic magmas producing large volumes of tephra occurred in the Rif-Betics area, Sardinia and the Pannonian Basin (Fig. 8) within and around the Mediterranean region. The age of the volcanic eruptions at the Rif-Betics region is dominantly Late Miocene-Pliocene, although minor silicic volcanism took place in Tell Atlas at 13-15 Ma (Duggen et al., 2008; Lustrino et al., 2011; Mattei et al., 2014). In Sardinia, vast amounts of calc-alkaline intermediate to silicic volcanic rocks were formed between 38 and $15 \mathrm{Ma}$, with a peak in volcanism around 22-18 Ma (Lustrino et al., 2009, 2013). The most evolved rocks are peralkaline trachytic to rhyolitic welded ignimbrites (Sulcis formation), which formed between $16.8 \pm 0.8 \mathrm{Ma}$ and $15.5 \pm 0.2 \mathrm{Ma}$ (Mundula et al., 2009). Thus, explosive eruptions of rhyolitic magmas in both Sardinia and the Pannonian Basin could potentially have affected large areas and could have provided distal tephra deposits during the Early to Mid-Miocene. Although the timing of activity in each of these volcanic centres overlaps to some degree, the chemical and mineralogical compositional signatures of their volcanic products are distinct and can be readily distinguished.

Within the Carpathian-Pannonian Region, a caldera-forming silicic ignimbrite was proposed to have been formed at the Oaş-Gutâi Volcanic Zone, East Carpathians at 15.4-14.8 Ma (K/Ar ages; Fülöp, 2002; Kovacs et al., 2017). The rare earth element patterns of these rhyolites resemble the pumices of the $14.36 \mathrm{Ma}$ Harsány ignimbrites. This is particularly remarkable, since Szakács and Fülöp (2002) considered the Gutâi ignimbrite as the proximal part of the Dej tuff (no. 11 in Fig. 8). Although Szakács et al. (2012) argued that the age of the Dej tuff is 14.8-15.1 Ma, de Leeuw et al. (2013) proposed a $14.38 \pm 0.06 \mathrm{Ma}$ age based on ${ }^{40} \mathrm{Ar} /{ }^{39} \mathrm{Ar}$ dating (Table 2). This latter age fits well with that of the Harsány ignimbrite and considering also the striking compositional similarities, we suggest that both the Gutâi and the Dej ignimbrites might have been related to the Harsány eruption. Presently, they are separated by about $250 \mathrm{~km}$, however, significant extension at the eastern part of the Pannonian Basin occurred during the late Miocene (Balázs et al., 2016) that could result in post-volcanic divergence. This hypothesis should be tested by further geochronological, volcanological and petrologic studies.

During the Mid-Miocene, the northern regions of the Mediterranean were covered by the Paratethys Sea in multiple sub-basins (e.g. Rögl, 1999), which could act as potential depocentres for accumulation and preservation of distal ash layers even at distances exceeding $1000 \mathrm{~km}$ 


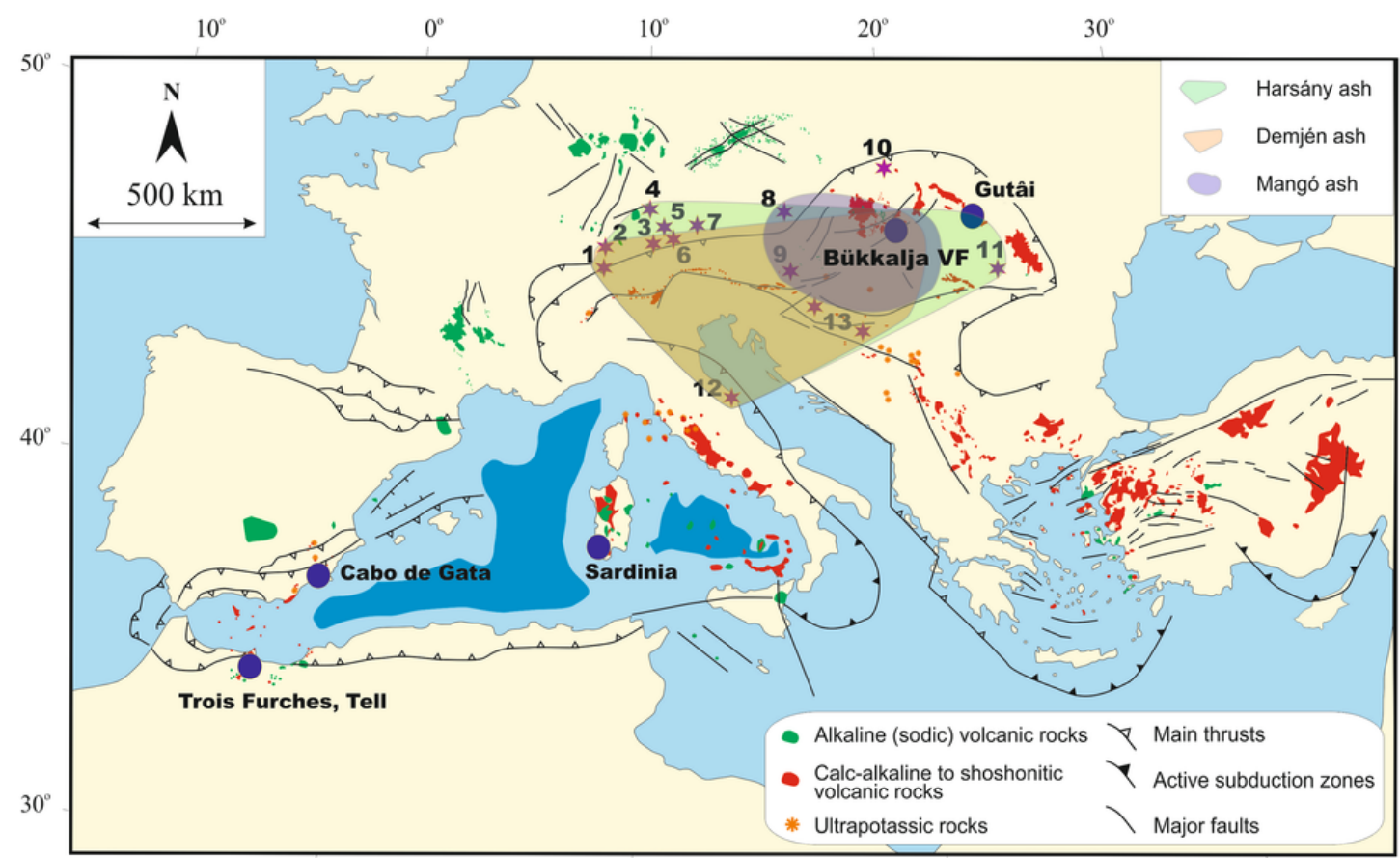

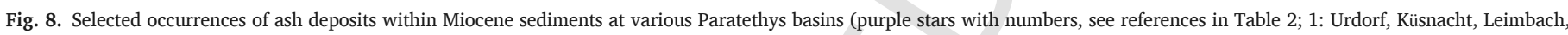

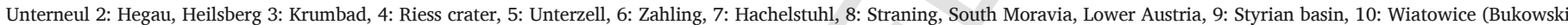

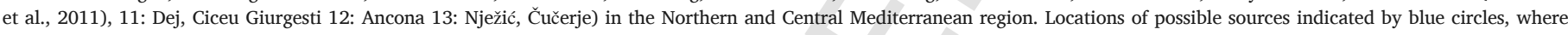

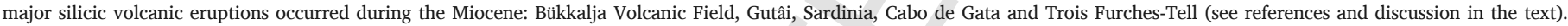

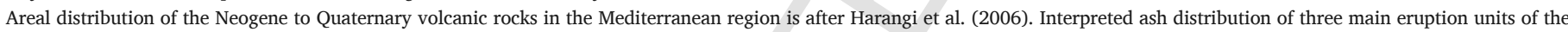

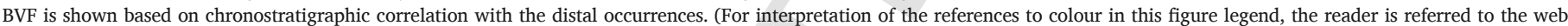
version of this article.)

from the eruption centres. The complex geodynamic evolution of the northern Mediterranean region resulted in repeated periods of isolation of the sub-basins, which have been characterized by distinct endemic fauna (Steininger et al., 1988; Magyar et al., 1999; Harzhauser et al., 2002; Kováč et al., 2007). This has resulted in difficulties in the Miocene biostratigraphic correlation and caused the establishment of local chronostratigraphy schemes for the Paratethys in central and eastern Europe (Steininger et al., 1988; Hohenegger et al., 2014). Furthermore, there are problems with the correlation of Mid-Miocene sedimentary deposits in this region with those found in the Mediterranean (Sant et al., 2017), where a high resolution chronostratigraphic framework was established on the basis of astronomically confirmed data (e.g., Hüsing et al., 2010; Wotzlaw et al., 2014) and forms the basis for the global Miocene timescale (Astronomical Tuned Neogene Time Scale; ATNTS04; Lourens et al., 2004). Precise dating of intercalated volcanic ash beds (Rocholl et al., 2017 and references therein) has allowed the correlation the occasionally separated sub-basins and the regional stages of the Paratethys and can help couple the sequences to global events (i.e. geomagnetic polarity reversals, sea-level cycles, astronomic events, climate cycles). In addition, radiometric data can be used to constrain the absolute timeframe of the depositional, biostratigraphic and palaeoecologic histories (e.g., Böhme, 2004; Kälin and Kempf, 2009).

The zircon U-Pb ages of the silicic volcanism of the Pannonian Basin presented in this paper provide a fundamental basis for correlative works. This volcanism appears to have been the most significant volcanic activity in Europe at that time and could have had a far-field impact over a large area (Fig. 8). Our new zircon U-Pb age data refine the tephrostratigraphic correlation proposed by Rocholl et al. (2017). Many Miocene tuffs, bentonites and ash-rich sedimentary (tuffites) deposits occur around the Pannonian Basin even at distances of several hundreds of kilometres (Fig. 8; Table 2). Most of them are younger than 15.5 Ma, and therefore cannot be the products of the volcanism in Sardinia. In contrast, the Miocene volcanism of the Pannonian Basin was already suggested to be the potential source of these volcanic deposits in some cases (Unger et al., 1990; Nehyba and Roetzel, 1999; Handler et al., 2006; Roetzel et al., 2014; Rocholl et al., 2017). The timing of this volcanism, i.e., from 18.2 to $14.4 \mathrm{Ma}$, partially or wholly covers the timing of stratigraphic sections of these sub-basins.

The published ages of the volcanic ash layers (Table 2) were determined both by ${ }^{40} \mathrm{Ar} /{ }^{39} \mathrm{Ar}$ on mineral and glass and single zircon U-Pb technique. They fit remarkably with the eruption ages of the BVF pyroclastic rocks (Table 2). In this paper, we provided high-precision single zircon $\mathrm{U}-\mathrm{Pb}$ dates for the main eruption episodes that confirm the interpretation of the LA-ICP-MS ages, but reduced their uncertainties. This enables a better correlation with the volcanic ash occurrences across Europe.

Five of the BVF volcanic events (17.5 Ma Eger and 17.1 Ma Mangó ignimbrite units; the $14.9 \mathrm{Ma}$ Demjén, the $14.7 \mathrm{Ma}$ Tibolddaróc and 14.4Ma Harsány units) can be correlated with the distal tephras, implying that large volumes of volcanic material were ejected (Table 2). Although the Gutâi Mountain has been considered a potential source of tephra occurrences in the Swiss Alps (Bischofszell; age: $14.417 \pm 0.009 \mathrm{Ma}$; Rocholl et al., 2017) and for the Dej tuff $(14.37 \pm 0.06 \mathrm{Ma}$; de Leeuw et al., 2013) in the Transylvanian basin, we suggest that these tephras were sourced from the eruption of the 14.4Ma Harsány ignimbrite. The large pumice clasts (up to $40 \mathrm{~cm}$ in size) in the Harsány ignimbrite outcrop at the eastern BVF indicate a near vent deposition (Lukács et al., 2009). Additionally, based on chronological and geochemical (overlapping rare-earth element patterns) similarities, we propose that the Dej tuff could also belong to this eruption event and represent its distal member. 
Table 2

Summary of occurrences and ages of volcanic ashes in Paratethys sub-basins and the Riess crater that could be possibly correlated with the BVF eruption units.

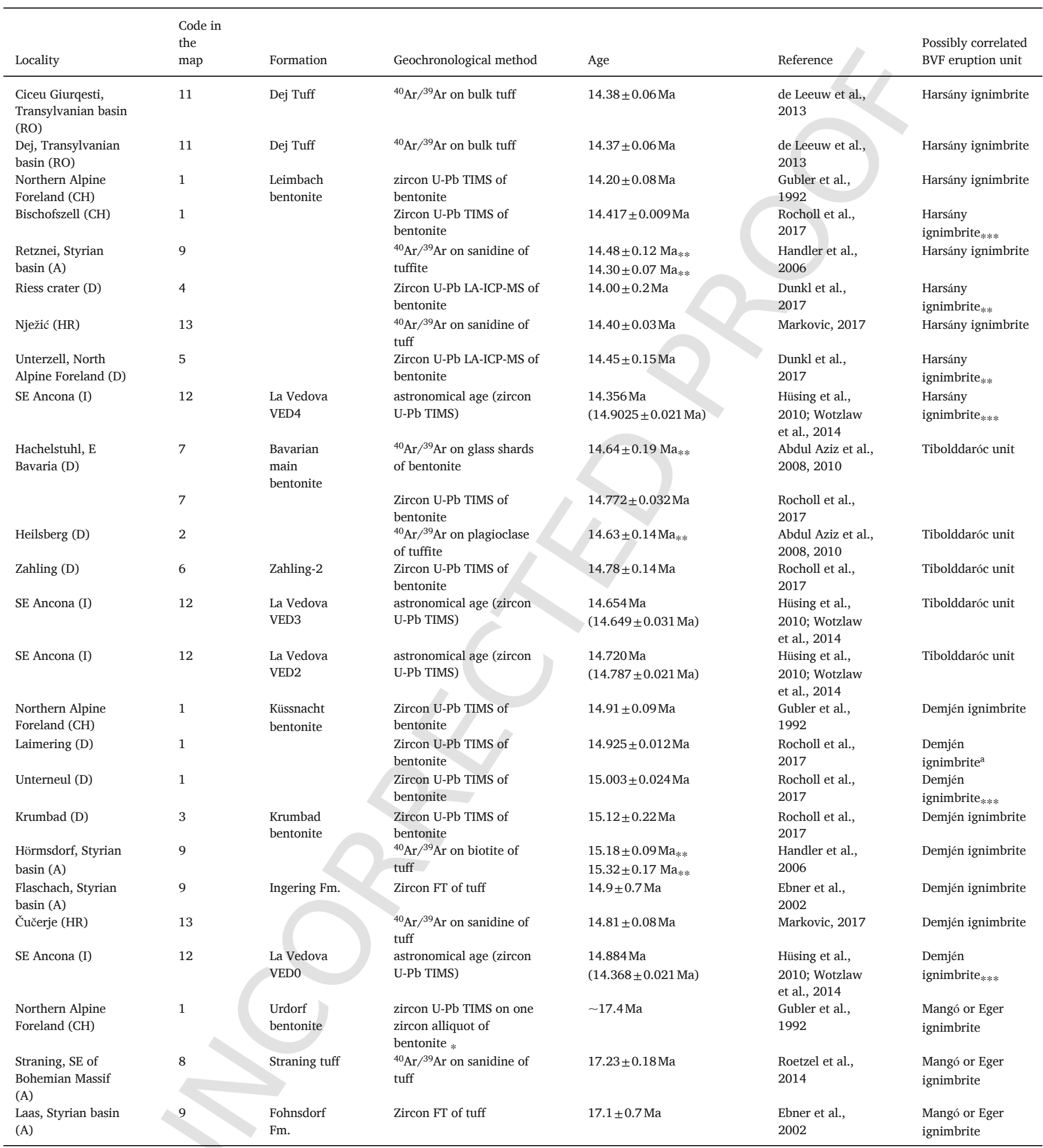

* Gubler et al., 1992 interpreted this age as inherited age component in the bentonite.

** recalculated according to Kuiper et al., 2008 by Rocholl et al., 2017.

**** Th/U ratio of zircon grains also support correlation.

**** Composition of allanite supports also this correlation.

a Not supported by the $\mathrm{Th} / \mathrm{U}$ ratio of zircon grains. 
The $14.880 \pm 0.014$ Ma Demjén ignimbrite eruption was probably even larger and tephras of similar age are found in the molasse basins of Switzerland (Küssnacht) and South Germany (Unterneul; ages from $14.91 \pm 0.09 \mathrm{Ma}$ to $15.003 \pm 0.024 \mathrm{Ma}$; Gubler et al., 1992 ; Rocholl et al., 2017; Table 2). Furthermore, Wotzlaw et al. (2014) described volcanic ash-bearing layers in the La Vedova deep marine sedimentary section near Ancona, east-central Italy, where zircon U-Pb ID-TIMS ages of two samples (VED0 and VED4) yielded eruption ages of $14.903 \pm 0.021$ $(14.874 \pm 0.021 \mathrm{Ma}$ for the youngest grain age and with an astronomical age of $14.884 \mathrm{Ma}$ ) and $14.368 \pm 0.021 \mathrm{Ma}$ weighted mean ages $(14.318 \pm 0.045 \mathrm{Ma}$ for the youngest grain age and with an astronomical age of $14.356 \mathrm{Ma}$ ) that correspond well with the interpreted eruption ages of the Demjén $(14.880 \pm 0.014 \mathrm{Ma})$ and Harsány $(14.358 \pm 0.015 \mathrm{Ma})$ ignimbrite events, respectively. Th/U ratios of the analyzed zircon grains of Harsány and Demjén unit and those of VED0 (and Bishofszell) and VED4 (and Unterneul), respectively are similar (Wotzlaw et al., 2014; Rocholl et al., 2017), however, more trace element comparisons of zircon populations could corroborate the possible correlation of the volcanic materials (Lukács et al., 2015). Moreover, volcanic ashes with similar Ar-Ar age as the Harsány and Demjén ignimbrites were described in Croatia (Markovic, 2017), southwest of the Pannonian Basin (Fig. 8; Table 2).

Volcanic ashes with ages indicating an origin from large volcanic eruptions of the Pannonian Basin were deposited dominantly in sedimentary basins west of the Carpathian-Pannonian region and therefore, they could provide further evidence for the atmospheric circulation pattern during the Mid-Miocene, just following the climatic optimum between 18 and $17 \mathrm{Ma}$ (Zachos et al., 2001). The inferred distribution of the distal tephras could corroborate the dominantly easterly winds during this period (Böhme, 2004; Rocholl et al., 2008).

In summary, distal deposits originating from the large volcanic eruptions of silicic magmas in the Pannonian Basin appear to be present at distances over several hundreds of kilometres from the source area. Ash beds in different Paratethys sub-basins in central Europe correlate well in age with the main volcanic events reported in this study and this suggests large, plinian/phreatoplinian-type eruptions in the Pannonian Basin during the Early to Mid-Miocene. Zircon-based studies involving determination of $\mathrm{U}-\mathrm{Pb}$ dates and trace element compositions in the distal deposits could provide further support for this cross-correlation, which would greatly improve our knowledge on the Early to Mid-Miocene stratigraphy and the chronological framework at the Mediterranean and surrounding regions.

\subsection{Silicic volcanism in extensional setting}

Silicic volcanism often occurs as multiple eruptive events ("fractal tempos"; de Silva et al., 2015) during prolonged (10-20 Ma) periods, when the successive eruptions of large volume magmas results in several tens-of-thousands of cubic kilometres of volcanic products and a strong thermomechanical impact of the continental crust (de Silva et al., 2006, 2015; de Silva and Gregg, 2014; Lipman and Bachmann, 2015). During these events, it is estimated that up to 3-4 times more magma volume is emplaced in the crust and erupted to the surface compared to steady-state volcanism (Lipman et al., 1972; Burns et al., 2015). This kind of silicic magmatism takes place mostly in continental arc settings characterized by thick continental crust. However, voluminous silicic volcanism also occurs in extensional continental settings with thinner continental crust, such as in the Basin and Range province in the western U.S. during the Miocene (Ratté et al., 1984; Gans et al., 1989; Colgan et al., 2006) and in the Taupo Volcanic Zone in northern New Zealand during the Quaternary (Cole, 1979; Cole et al., 1995; Spinks et al., 2005; Wilson et al., 2009; Deering et al., 2010; Wilson and Rowland, 2016). Both regions produced several thousands of cubic kilometres of dacitic to rhyolitic ignimbrites and related volcanic products. Their isotopic compositions suggest a strong mantle contribution to the magma genesis (McCulloch et al., 1994), consistent with thinning continental crust during the volcanism.

The nature and behaviour of silicic magmatic systems depend upon the variable roles of mantle power (i.e. rate of basaltic magma intrusion into the lower crust), the thermomechanical modulation of the upper crust, the duration of such an event and tectonic forcing over time (Hildreth, 1981; de Silva and Gosnold, 2007; de Silva and Gregg, 2014; de Silva et al., 2015; Best et al., 2016; Gravley et al., 2016; Karakas et al., 2017). In the Pannonian Basin, cumulatively $>4000 \mathrm{~km}^{3}$ volcanic material could have been erupted during a $4 \mathrm{Myr}$ period that corresponds ca. $5 \times 10^{-3}$ to $10^{-2} \mathrm{~km}^{3} \mathrm{yr}^{-1}$ magma flux into the crust, assuming a 5-10:1 plutonic/volcanic ratio (an intermediate value between the high- and low-flux systems; Hildreth, 1981; de Silva et al., 2015; Karakas et al., 2017). Based on the zircon crystallization age data (Fig. 9), the onset of the silicic volcanism was likely preceded by intrusions and emplacement of magmas into the continental crust for a prolonged period ( $>1 \mathrm{Myr}$ ). From 18.5 Ma, a complex upper crustal storage system could have developed, where occasionally eruptible, i.e. melt-rich silicic magmas, could separate and feed eruptions. Lukács et al. (2015) pointed out that individual silicic magma reservoirs in the Pannonian Basin had a lifetime of several 100'skyr, consistent with the longevity of other silicic volcanic systems (Caricchi et al., 2014; Lipman and Bachmann, 2015).

de Silva et al. (2015) argued that a thermally matured crust is necessary to enable a large amount of silicic magma to accumulate in the upper crust. This can be due to emplacement of mantle-derived basaltic magmas in the lower crust for $>10^{6} \mathrm{yr}$, followed by ascent of interme-

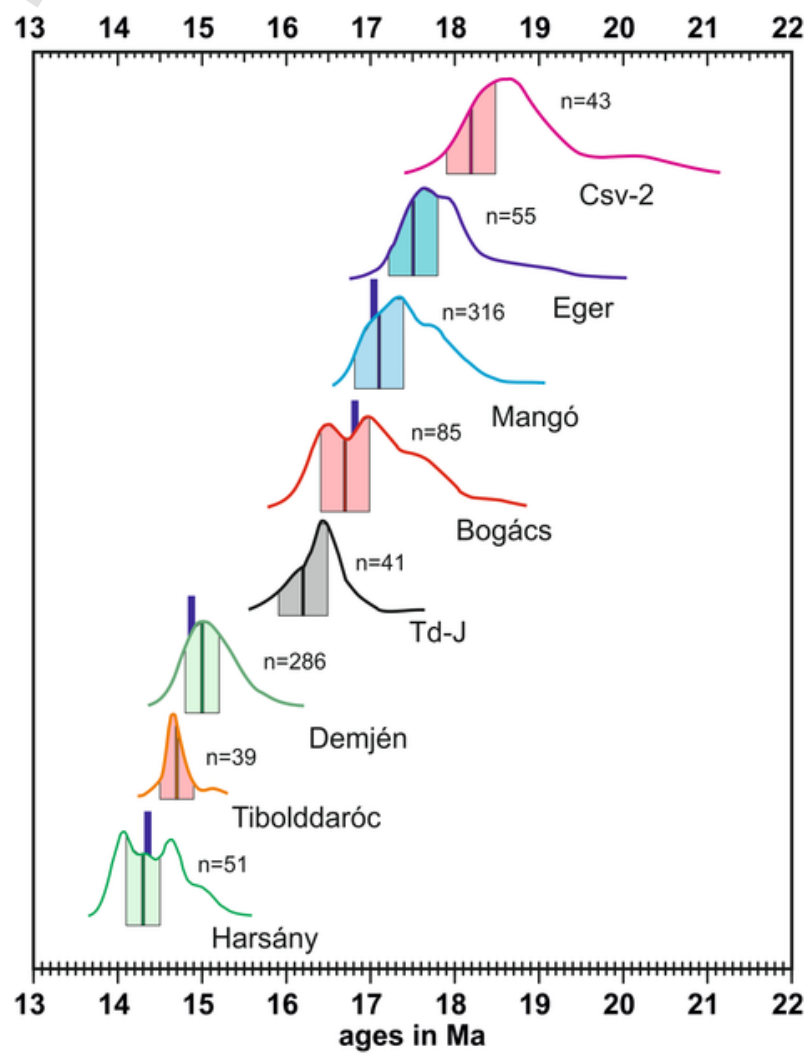

Fig. 9. Eruption age distribution of the BVF silicic volcanism shown by Kernel density estimation curves (Vermeesch, 2012) of interpreted LA-ICP-MS eruption ages with uncertainties and bars of more accurate ID-TIMS and ${ }^{40} \mathrm{Ar} /{ }^{39} \mathrm{Ar}$ ages. 
diate magmas to the upper crust that results in thermal maturation and shallowing of the brittle-ductile transition (de Silva, 2008; Karakas et al., 2017). This thermomechanical state of the crust enables the formation and storage of silicic magmas over several 100's to 1000's kyr, even at a relatively low magma intrusion rate. Karakas et al. (2017) pointed out that the duration of magma intrusion has as much importance as the mantle power (de Silva et al., 2015) in the development of large volumes of silicic mushy magma in the crust, while the tectonic setting, thickness of the crust, and initial thermal state (e.g., potential pre-warming) may also play an important role in crustal maturation (Best et al., 2016; Karakas and Dufek, 2015).

At the beginning of the evolution of the Carpathian-Pannonian Region (early Miocene), the thickness of the continental crust was as much as $50 \mathrm{~km}$, indicated by calculations from present-day crustal thickness and the determined stretching factors as well as petrologic studies of lower crustal granulite xenoliths (Tari et al., 1999; Lenkey et al., 2002; Embey-Isztin et al., 2003; Török et al., 2005; Horváth et al., 2006). It now has thinned to about half of it, while the lithospheric mantle underwent even more significant stretching during the Middle Miocene (Horváth, 1993; Horváth et al., 2006). Tari et al. (1999) proposed that thick and hot crust during the Early Miocene led to core-complex style extension in certain areas of the Pannonian Basin. This implies that, prior to extension, the crust was already warmed by pre-Neogene orogenic processes. This pre-warmed state of the thick crust and the accelerated thinning of the lithospheric mantle could promote mantle melting. Basaltic magmas accumulated beneath the thick crust and differentiated dominantly by AFC (assimilation fractional crystallization) in a lower crustal MASH zone (i.e., melting, assimilation, storage and homogenization; Hildreth and Moorbath, 1988, Walker et al., 2015). Some of the evolved magmas with andesitic to dacitic compositions caused sporadic volcanism during the Early Miocene and developed lava dome fields in the central to southern Pannonian Basin (Komló, Paks) as shown by borehole data and seismic sections. Granodioritic intrusion and dacitic volcanism in the SW Pannonian Basin can also belong to this stage of magmatism (18.65 Ma, Fodor et al., 2008). As the crust thermally matured, large upper crustal reservoirs could form, fostering the most intense silicic phase of volcanism (late Early to Mid-Miocene), contemporaneously with the major crustal and lithospheric thinning of the Pannonian Basin. The strong thermomechanical impact on the continental crust resulted in an anomalously high temperature gradient and maturation of organic material in the upper crust (Horváth et al., 1988, 2015; Sachsenhofer et al., 1998). Partial or complete resetting of low-temperature thermochronometers at $\sim 17 \mathrm{Ma}$ (apatite fission track, [U-Th]/He) detected at various locations in the Pannonian Basin (Dunkl and Frisch, 2002; Danišík et al., 2012, 2015) supports the regional increase of the heat flow. Furthermore, the Neogene age of most of the zircons in metasedimentary granulite xenoliths hosted by Late Miocene alkaline basalts in the central Pannonian Basin suggests that the temperature at the base of the continental crust was sufficiently high to reset the zircon age (Downes et al., 2015), i.e. it could intermittently exceed even the closure temperature of $\mathrm{U}$ and $\mathrm{Pb}$ isotopes in zircons. Remarkably, peak ages of zircons occur at 17-20 Ma and 2-5 Ma (Downes et al., 2015), corresponding with the silicic and the subsequent alkaline basaltic volcanism.

\subsection{Origin of silicic volcanism in the Pannonian Basin}

The zircon $\mathrm{U}-\mathrm{Pb}$ dates presented in this paper suggest that large silicic volcanic activity lasted from $18.2 \mathrm{Ma}$ to $14.4 \mathrm{Ma}$ in the Pannonian Basin and involved at least four large-volume volcanic events. Based on the estimated volume of the erupted material this event falls in the category of tertiary pulses (de Silva et al., 2015) or Category 2 flare-up (Gravley et al., 2016). Eruptions of silicic magmas occurred in two main pulses (from 18.2 to $16.2 \mathrm{Ma}$ and from 15 to $14.4 \mathrm{Ma}$, respectively; Fig. 9) separated by a $1.3 \pm 0.3 \mathrm{Myr}$ gap between $16.2 \pm 0.3$ and $14.880 \pm 0.014 \mathrm{Ma}$. This gap between the main silicic eruption phases coincides with major calc-alkaline andesitic to dacitic volcanism in the northern Pannonian Basin (Harangi et al., 2007), associated with graben formation along normal faults (Nemčok and Lexa, 1990; Harangi et al., 2001). This could have promoted fast evacuation of magmas from deep crustal reservoirs. Thus, renewal of the silicic volcanism occurred in a changing tectonic environment, when the lithosphere already thinned considerably. This is clearly reflected in the less enriched isotopic composition of the younger pumices and zircons.

Silicic magmas erupted during the first pulse were generated in a geodynamic environment, when the continental crust was already thermally matured. Pumices and zircons in these volcanic products have an enriched isotopic character (e.g., ${ }^{87} \mathrm{Sr} /{ }^{86} \mathrm{Sr}_{\mathrm{i}}=0.7095-0.7115$ in pumices and $\varepsilon \mathrm{Hf} \leq 5$ in zircons), consistent with crustal anatexis (Póka, 1988; Lexa and Konečný, 1998; Seghedi and Downes, 2011). Anatexis of the lower crust could have occurred due to underplating of mafic magma derived from metasomatized asthenospheric mantle wedge above a subducted slab (Seghedi et al., 2014). However, pure crustal anatexis is unlikely to be an efficient mechanism, considering the heat budget in the crust (e.g., Thompson et al., 2002; Dufek and Bergantz, 2005; Annen et al., 2006). Furthermore, the sporadic occurrence of significantly older zircon age domains/crystals in the BVF samples (Lukács et al., submitted) also does not support significant crustal melting. Crystal fractionation from mafic parents combined with crustal contamination seems to be more likely to generate large volume of intermediate magmas (see Bachmann and Huber, 2016 for a review of such arguments). Indeed, the role of mantle-derived mafic magmas in the origin of the silicic volcanism of the Pannonian Basin is shown by the occasional occurrence of high-Mg orthopyroxenes and An-rich plagioclases in the BVF rocks (Lukács et al., 2005; Czuppon et al., 2012).

The isotopic composition of the erupted silicic volcanic products reflects either enriched mantle source character and/or involvement of variable amount of crustal material. Melting of asthenospheric mantle beneath thick ( $>150 \mathrm{~km}$ ) lithosphere seems to be less probable, whereas partial melting of the metasomatized lower lithosphere by decompression during thinning could result in mafic magma. There is no geological evidence for active subduction beneath this region during the Early Miocene, while lithospheric extension already initiated at around 20 Ma (Horváth, 1993,Horváth et al., 2006; Balázs et al., 2017). Melting of lithosphere requires fusible material such as originated during past subduction-related metasomatism. Thus, the generated mafic magma will have a 'subduction-component' with enriched isotopic features as shown by Harangi et al. (1995, 2001, 2007) for the Mid-Miocene volcanism in the Pannonian Basin. Cognate basaltic andesite lithoclasts with such compositional feature are found even in the silicic ignimbrites (Harangi and Lenkey, 2007) that could represent the mafic end-member evolved further by AFC (assimilation of crustal material during fractional crystallization) to produce more evolved magmas mostly in and around the lower crustal MASH zone. These differentiated magmas ascended intermittently in the upper crust and developed heterogeneous magma reservoirs. Mafic magmas were occasionally able to ascend and intrude into this upper crustal silicic crystal mush body, as shown by the reversely and oscillatory zoned orthopyroxene crystals (Lukács et al., 2005; Czuppon et al., 2012). Such replenishment events resulted in thorough mixing/mingling of crystal mush layers and melt lenses as reflected by the volcanic products of the Bogács unit (Czuppon et al., 2012). Eruption of the mafic magmas was prevented by the density filter of the vast amount of silicic crystal mush bodies in the crust, but reached the surface following the termination of the silicic volcanism. 
In summary, the Early to Mid-Miocene silicic volcanism in the Carpathian-Pannonian Region can be regarded as bimodal basalt-rhyolite magmatism even though the mafic magmas did not often reach the surface (as happened in the TVZ; Wilson et al., 1995, and see below). Andesitic lithoclasts and juvenile material in the Bogács unit are considered to be the mixed product of the mafic and silicic magmas (Lukács et al., 2005; Harangi and Lenkey, 2007; Czuppon et al., 2012).

The pumices and zircons belonging to the younger, 14-15 Ma volcanic events have a isotopic compositions distinct from the older volcanic event (Fig. 10; Harangi and Lenkey, 2007). They show less enriched isotope character, implying significantly less crustal component and/or an increase of addition of asthenospheric mantle-derived magmas. This change could be attributed to significant thinning of the lithosphere including the crust by this time, which enabled increased asthenospheric mantle input to the magma generation.

We note that the study area occupies the northern fault zones of the major Mid-Hungarian Shear Zone (MHZ). In addition to normal faulting, strike-slip deformation has been documented in several sub-basins (Tari, 1988; Petrik et al., 2016). This phase of deformation also involved verical axis rotations (Márton and Márton, 1996; Márton and Fodor, 1995). The second pulse of the silicic volcanism occurred during a second major phase of syn-rift deformation, between 15 and $9 \mathrm{Ma}$, which kept a transtensional character (Petrik et al., 2014; Petrik, 2016). All these deformations provided weakened zones, enhancing magma movements and evacuation.

This tectonic situation is remarkably similar to that described for the silicic volcanism at the Taupo Volcanic Zone (Cole, 1990; Wilson et al., 1995; Spinks et al., 2005). This is an actively rifting area with attenuated lithosphere and high heat flux formed at a convergent plate boundary between the Pacific and Australian plates. The caldera complexes were formed along the axis of the rift zone characterized by normal faults with some strike-slip character. This setting is parallel with the North Island Shear Belt or North Island Dextral Fault Belt, which is a zone of dominantly strike-slip faulting, related to the rotation of the eastern North Island (Cole, 1990; Cole and Spinks, 2009). The caldera complexes produced multiple ignimbrite-forming eruptions often with large erupted volumes (Wilson et al., 2009; Wilson and Rowland, 2016). The back-arc setting, the close association between volcanism and rifting, and close structural control by normal and strike-slip faults, are also all characteristic of the Pannonian Basin during the Miocene. Association between large caldera complexes and regions of extension, involving pull-apart basins along strike-slip shear zones and block rotations, has been described also in the Andes (de Silva, 1989; Riller et al., 2001), western US (Mono-Inyo Craters, Mammoth Mountain and Long
Valley Caldera, California; Riley et al., 2012), Mexico (Tibaldi, 1992) and El Salvador (Saxby et al., 2016), among others. Magma generation at depth could have been controlled by decompression melting of the upper mantle due to lithospheric thinning, while normal faulting, block rotations and strike-slip tectonics facilitated the ascent of magma.

\section{Conclusion}

Eruption chronology of a massive Miocene silicic volcanism episode in Europe has been determined based on >1400 LA-ICP-MS U-Pb zircon dates from 19 samples complemented by high-precision CA-ID-TIMS zircon dates from 4 samples collected in the Bükkalja Volcanic Field, North Hungary. Accuracy of the eruption ages is supported by the similar results obtained from two different laboratories, using different analytical and data-reduction procedures, as well as the concordant ID-TIMS zircon and Ar-Ar sanidine ages. The new results highlight the regional geologic importance of this poorly-known volcanic activity in Europe that had a continental scale impact and their volcanic products can now be used to constrain better the Paratethys chronostratigraphy. The silicic volcanism occurred between 18.2 Ma and 14.4 Ma, concurrent with major lithospheric thinning in the Pannonian Basin. Relatively fast thermomechanical maturation of the upper crust prior to the silicic volcanism may have been caused by warming during pre-rifting orogenic events. Silicic magmas are inferred to have formed primarily by AFC process from lithospheric mantle-derived mafic magmas. Hafnium isotope data of zircons and bulk rock Sr-Nd isotope values indicate an abrupt change in the magma sources after $16.2 \mathrm{Ma}$, suggesting a decrease of crustal component and/or an increase of asthenospheric mantle-derived magmas that is consistent with the progression of the lithospheric extension by that time.

The volcanism shows many similarities with other regions of continental rift-related silicic volcanic activity such as those in the Taupo Volcanic Zone (New Zealand) and the Basin and Range province (USA). Extension, strike-slip faulting and microplate rotations occurred contemporaneously with the silicic volcanism and this deformation provided weakened zones, where long-lasting silicic magma reservoirs could develop and occasional evacuation of large volume rhyodacitic to rhyolitic magmas could occur. The continental crust was affected by a strong thermomechanical impact contributing also to the maturation of organic material.

This volcanic activity was one of the most voluminous in Europe during the last $20 \mathrm{Myr}$ and the largest one during the Miocene. The 4-Myr long volcanism involved at least 8 eruptive phases and a few of them resulted in several 10's or even 100's of cubic kilometre of vol-

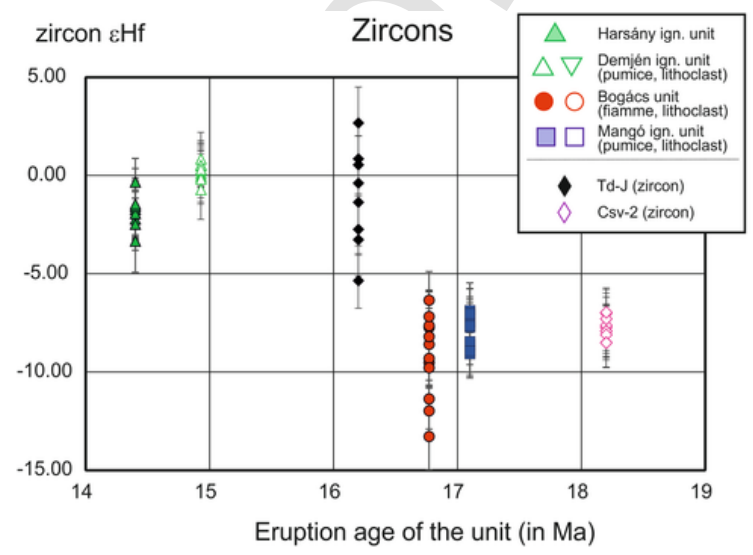

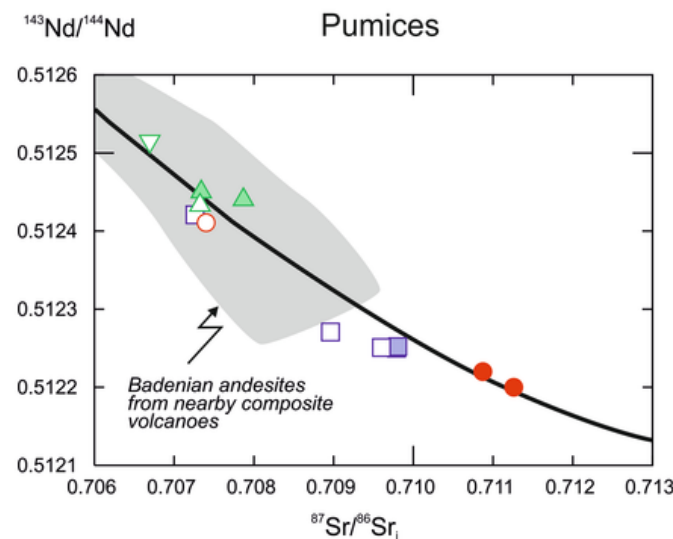

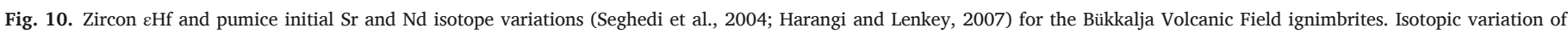

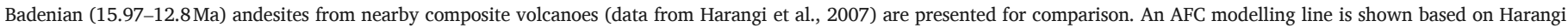
et al. (2001). 
canic material, which covered much of the Carpathian-Pannonian region. Distal tephras can be found in the sedimentary sequences of the isolated Paratethys sub-basins at the surroundings of the Carpathian-Pannonian Region and over $1000 \mathrm{~km}$ distance along the northern Alps and the central Mediterranean. Many of the published ages of these volcanic ashes show a remarkable fit with the largest eruption phases of this silicic volcanism, supporting the dominantly easterly winds during the Mid-Miocene. This prompts further zircon perspective correlation studies, which could help to construct a high-resolution chronostratigraphic framework to achieve a better correlation of different Paratethys stages in the Mediterranean and to yield precise age proxies that could contribute to connect these sequences to global events. The present study demonstrates that LA-ICP-MS zircon dating technique provides a fast, cheap and accurate method for such work.

\section{Acknowledgements}

This study was financed by the Hungarian National Research, Development and Innovation Fund (NKFIH) within two postdoctoral projects for Réka Lukács (PD112584 and PD121048). Réka Lukács was also supported by the János Bolyai Research Scholarship of the Hungarian Academy of Sciences and by a short-term visit supported by Campus Hungary Fellowship to ETH, Zürich in 2014 (B2/4R/12728). Initial phase of the research was supported by the OTKA grant 81530 led by L. Fodor. The GATAN MiniCL facility belongs to the KMP project nr. 4.2.1/ B-10-2011-0002 supported by the European Union. We thank Ben Ellis for the final language check. The anonymous reviewers gave us constructive suggestions that helped us to clarify our conclusions and improved the manuscript.

\section{References}

Abdul Aziz, H., Böhme, M., Rocholl, A., Prieto, J., Wijbrans, J.R., Bachtadse, V., Ulbig, A., 2010. Integrated stratigraphy and ${ }^{40} \mathrm{Ar} /{ }^{39} \mathrm{Ar}$ chronology of the early to middle Miocene Upper Freshwater Molasse in western Bavaria (Germany). Int. J. Earth Sci. 99 (8), 1859-1886.

Abdul Aziz, H., Böhme, M., Rocholl, A., Zwing, A., Prieto, J., Wijbrans, J.R., Heissig, K., Bachtadse, V., 2008. Integrated stratigraphy and ${ }^{40} \mathrm{Ar} /{ }^{39} \mathrm{Ar}$ chronology of the Early to Middle Miocene Upper Freshwater Molasse in eastern Bavaria (Germany). Int. J. Earth Sci. 97 (1), 115-134.

Annen, C., Blundy, J.D., Sparks, R.S.J., 2006. The genesis of intermediate and silicic magmas in deep crustal hot zones. J. Petrol. 47 (3), 505-539.

Bachmann, O., Bergantz, G.W., 2008. Rhyolites and their source mushes across tectonic settings. J. Petrol. 49, 2277-2285.

Bachmann, O., Charlier, B.L.A., Lowenstern, J.B., 2007. Zircon crystallization and recycling in the magma chamber of the rhyolitic Kos Plateau Tuff (Aegean arc). Geology 35 (1), 73-76.

Bachmann, O., Huber, C., 2016. Silicic magma reservoirs in the Earth's crust. Am. Mineral. 101 (11), 2377-2404.

Balázs, A., Burov, E., Matenco, L., Vogt, K., Francois, T., Cloetingh, S., 2017. Symmetry during the syn- and post-rift evolution of extensional back-arc basins: the role of inherited orogenic structures. Earth Planet. Sci. Lett. 462, 86-98.

Balázs, A., Maţenco, L., Magyar, I., Horváth, F., Cloetingh, S., 2016. The link between tectonics and sedimentation in back-arc basins: new genetic constraints from the analysis of the Pannonian Basin. Tectonics 35 (6), 1526-1559.

Balla, Z., 1984. The Carpathian loop and Pannonian Basin: a kinematic analysis. Geophys. Trans. 30, 313-355.

Best, M.G., Christiansen, E.H., de Silva, S., Lipman, P.W., 2016. Slab-rollback ignimbrite flareups in the southern Great Basin and other Cenozoic American arcs: a distinct style of arc volcanism. Geosphere 12 (4), 1097-1135.

Best, M.G., Christiansen, E.H., Gromme, S., 2013. Introduction: the 36-18Ma southern Great Basin, USA, ignimbrite province and flareup: swarms of subduction-related supervolcanoes. Geosphere 9 (2), 260-274

Böhme, M., 2004. Migration history of air-breathing fishes reveals Neogene atmospheric circulation patterns. Geology 32 (5), 393-396.

Bukowski, K., de Leeuw, A., Gonera, M., Kuiper, K.F., Krzywiec, P., Peryt, D., 2011. Badenian tuffite levels within the Carpathian orogenic front (Gdów-Bochnia area, Southern Poland): radio-isotopic dating and stratigraphic position. Geological Quarterly 54 (4), 16.

Burns, D.H., de Silva, S.L., Tepley, F., Schmitt, A.K., Loewen, M.W., 2015. Recording the transition from flare-up to steady-state arc magmatism at the Purico-Chascon volcanic complex, northern Chile. Earth Planet. Sci. Lett. 422, 75-86.
Capaccioni, B., Coradossi, N., Harangi, R., Harangi, S., Karátson, D., Sarocchi, D., Valentini, L., 1995. Early Miocene pyroclastc rocks of the Bükkalja Ignimbrite Field (North Hungary)—a preliminary stratigraphic report. In: Downes, H., Vaselli, O. (Eds.), Neogene and Related Volcanism in the Carpatho-Pannonian Region. Acta Vulcanol., vol. 7, pp. 119-124.

Caricchi, L., Simpson, G., Schaltegger, U., 2014. Zircons reveal magma fluxes in the Earth's crust. Nature 511 (7510), 457-461.

Carminati, E., Lustrino, M., Cuffaro, M., Doglioni, C., 2010. Tectonics, magmatism and geodynamics of Italy: what we know and what we imagine. J. Virtual Explor. 36.

Carminati, E., Lustrino, M., Doglioni, C., 2012. Geodynamic evolution of the central and western Mediterranean: tectonics vs. igneous petrology constraints. Tectonophysics 579, 173-192.

Cherniak, D.J., Hanchar, J.M., Watson, E.B., 1997. Diffusion of tetravalent cations in zircon. Contrib. Mineral. Petrol. 127 (4), 383-390.

Cole, J.W., 1979. Structure, petrology, and genesis of Cenozoic volcanism, Taupo Volcanic Zone, New Zealand-a review. N. Z. J. Geol. Geophys. 22 (6), 631-657.

Cole, J.W., 1990. Structural control and origin of volcanism in the Taupo volcanic zone, New Zealand. Bull. Volcanol. 52 (6), 445-459.

Cole, J.W., Darby, D.J., Stern, T.A., 1995. Taupo Volcanic Zone and Central Volcanic Region Backarc structures of North Island, New Zealand. In: Taylor, B. (Ed.), Backarc Basins: Tectonics and Magmatism. Springer US, Boston, MA, pp. 1-28.

Cole, J.W., Spinks, K.D., 2009. Caldera volcanism and rift structure in the Taupo Volcanic Zone, New Zealand. Geol. Soc. Lond., Spec. Publ. 327 (1), 9-29.

Colgan, J.P., Dumitru, T.A., McWilliams, M., Miller, E.L., 2006. Timing of Cenozoic volcanism and basin and range extension in northwestern Nevada: new constraints from the northern Pine Forest Range. Geol. Soc. Am. Bull. 118 (1-2), 126-139.

Conticelli, S., Guarnieri, L., Farinelli, A., Mattei, M., Avanzinelli, R., Bianchini, G., Boari, E., Tommasini, S., Tiepolo, M., Prelević, D., Venturelli, G., 2009. Trace elements and $\mathrm{Sr}-\mathrm{Nd}-\mathrm{Pb}$ isotopes of K-rich, shoshonitic, and calc-alkaline magmatism of the Western Mediterranean Region: genesis of ultrapotassic to calc-alkaline magmatic associations in a post-collisional geodynamic setting. Lithos 107 (1-2), 68-92.

Cooper, K.M., 2015. Timescales of crustal magma reservoir processes: insights from U-series crystal ages. Geol. Soc. Lond., Spec. Publ. 422, https://doi.org/10.1144/SP422.7.

Cooper, K.M., Kent, A.J.R., 2014. Rapid remobilization of magmatic crystals kept in cold storage. Nature 506 (7489), 480-483.

Costa, F., 2008. Chapter 1 residence times of silicic magmas associated with calderas. Developments in Volcanology 10, 1-55.

Crowley, J.L., Schoene, B., Bowring, S.A., 2007. U-Pb dating of zircon in the Bishop Tuff at the millennial scale. Geology 35 (12), 1123-1126.

Csontos, L., 1995. Tertiary tectonic evolution of the Intra-Carpathian area: a review. Acta Vulcanol. 7, 1-13.

Csontos, L., Nagymarosy, A., 1998. The Mid-Hungarian line: a zone of repeated tectonic inversions. Tectonophysics 297 (1-4), 51-71.

Csontos, L., Nagymarosy, A., Horváth, F., Kovác, M., 1992. Cenozoic evolution of the Intra-Carpathian area: a model. Tectonophysics 208, 221-241.

Czuppon, G., Lukács, R., Harangi, S., Mason, P.R.D., Ntaflos, T., 2012. Mixing of crystal mushes and melts in the genesis of the Bogács Ignimbrite suite, northern Hungary: an integrated geochemical investigation of mineral phases and glasses. Lithos 148, 71-85.

Dando, B.D.E., Stuart, G.W., Houseman, G.A., Hegedüs, E., Brückl, E., Radovanović, S., 2011. Teleseismic tomography of the mantle in the Carpathian-Pannonian region of central Europe. Geophys. J. Int. 186 (1), 11-31.

Danišík, M., Fodor, L., Dunkl, I., Gerdes, A., Csizmeg, J., Hámor-Vidó, M., Evans, N.J., 2015. A multi-system geochronology in the Ad-3 borehole, Pannonian Basin (Hungary) with implications for dating volcanic rocks by low-temperature thermochronology and for interpretation of (U-Th)/He data. Terra Nova 27 (4), 258-269.

Danišík, M., Shane, P., Schmitt, A.K., Hogg, A., Santos, G.M., Storm, S., Evans, N.J., Keith Fifield, L., Lindsay, J.M., 2012. Re-anchoring the late Pleistocene tephrochronology of New Zealand based on concordant radiocarbon ages and combined ${ }^{238} \mathrm{U} /{ }^{230} \mathrm{Th}$ disequilibrium and (U-Th)/He zircon ages. Earth Planet. Sci. Lett. 349, 240-250.

de Leeuw, A., Filipescu, S., Matenco, L., Krijgsman, W., Kuiper, K., Stoica, M., 2013. Paleomagnetic and chronostratigraphic constraints on the Middle to Late Miocene evolution of the Transylvanian Basin (Romania): implications for Central Paratethys stratigraphy and emplacement of the Tisza-Dacia plate. Glob. Planet. Chang. 103, 82-98.

de Silva, S., 2008. Arc magmatism, calderas, and supervolcanoes. Geology 36 (8), 671-672.

de Silva, S., Zandt, G., Trumbull, R., Viramonte, J.G., Salas, G., Jiménez, N., 2006. Large ignimbrite eruptions and volcano-tectonic depressions in the Central Andes: a thermomechanical perspective. Geol. Soc. Lond., Spec. Publ. 269 (1), 47-63.

de Silva, S.L., 1989. Altiplano-Puna volcanic complex of the central Andes. Geology 17 (12), 1102-1106.

de Silva, S.L., Gosnold, W.D., 2007. Episodic construction of batholiths: insights from the spatiotemporal development of an ignimbrite flare-up. J. Volcanol. Geotherm. Res. 167 (1), 320-335.

de Silva, S.L., Gregg, P.M., 2014. Thermomechanical feedbacks in magmatic systems: implications for growth, longevity, and evolution of large caldera-forming magma reservoirs and their supereruptions. J. Volcanol. Geotherm. Res. 282, 77-91.

de Silva, S.L., Riggs, N.R., Barth, A.P., 2015. Quickening the pulse: fractal tempos in continental arc magmatism. Elements 11 (2), 113-118. 
Deering, C.D., Gravley, D.M., Vogel, T.A., Cole, J.W., Leonard, G.S., 2010. Origins of cold-wet-oxidizing to hot-dry-reducing rhyolite magma cycles and distribution in the Taupo Volcanic Zone, New Zealand. Contrib. Mineral. Petrol. 160 (4), 609-629.

Doglioni, C., 1992. Main differences between thrust belts. Terra Nova 4 (2), 152-164.

Dombrádi, E., Sokoutis, D., Bada, G., Cloetingh, S., Horváth, F., 2010. Modelling recent de formation of the Pannonian lithosphere: lithospheric folding and tectonic topography. Tectonophysics 484 (1-4), 103-118.

Downes, H., Carter, A., Armstrong, R., Dobosi, G., Embey-Isztin, A., 2015. Lower crustal zircons reveal Neogene metamorphism beneath the Pannonian Basin (Hungary). Open Geosciences 7, 223-233.

Dufek, J., Bergantz, G.W., 2005. Lower crustal magma genesis and preservation: a stochastic framework for the evaluation of basalt-crust interaction. J. Petrol. 46 (11), 2167-2195.

Duggen, S., Hoernle, K., Klügel, A., Geldmacher, J., Thirlwall, M., Hauff, F., Lowry, D., Oates, N., 2008. Geochemical zonation of the Miocene Alborán Basin volcanism (westernmost Mediterranean): geodynamic implications. Contrib. Mineral. Petrol. 156 (5), 577.

Dunkl, I., Arp, G., Jung, D., Lukács, R., Eynatten, H., 2017. Allanite as Provenance Indicator of Volcanic Ashes. Goldschmidt2017, (Abstract).

Dunkl, I., Frisch, W., 2002. Thermochronologic constraints on the Late Cenozoic exhumation along the Alpine and West Carpathian margins of the Pannonian Basin. In: Cloetingh, S.A.P.L., Horváth, F., Bada, G., Lankreier, A.C. (Eds.), Neotectonics and Surface Processes: the Pannonian Basin and Alpine/Carpathian system. EGU Stephan Mueller Special Publication Series, vol. 3, pp. 120-134.

Ebner, F., Dunkl, I., Mali, H., Sachsenhofer, R.F., 2002. Stratigraphyic evidence of pyroclastic layers in Miocene basins of the Eastern Alps (Austria). In: Proceedings of the XVII. Congress of the Carpathian-Balkan Geological Association, Bratislava, September 1-4 2002. Geol. Carpathica, Spec. Issue, CD-ROM, vol. 53, pp. 1-5.

Embey-Isztin, A., Downes, H., Kempton, P.D., Dobosi, G., Thirlwall, M., 2003. Lower crustal granulite xenoliths from the Pannonian Basin, Hungary. Part 1: mineral chemistry, thermobarometry and petrology. Contrib. Mineral. Petrol. 144 (6), 652-670.

Fillerup, M.A., Knapp, J.H., Knapp, C.C., Raileanu, V., 2010. Mantle earthquakes in the absence of subduction? Continental delamination in the Romanian Carpathians. Lithosphere 2 (5), 333-340.

Fodor, L., Csontos, L., Bada, G., Györfi, I., Benkovics, L., 1999. Tertiary tectonic evolution of the Pannonian Basin system and neighbouring orogens: a new synthesis of paleostress data. In: Durand, B., Jolivet, L., Horváth, F., Séranne, M. (Eds.), The Mediterranean Basins: Tertiary Extension Within Alpine Orogen. Geological Society, London, Special Publications, vol. 156, pp. 295-334.

Fodor, L., Jelen, B., Márton, E., Skaberne, D., Čar, J., Vrabec, M., 1998. Miocene-Pliocene tectonic evolution of the Slovenian Periadriatic fault: implications for Alpine-Carpathian extrusion models. Tectonics 17 (5), 690-709.

Fodor, L.I., Gerdes, A., Dunkl, I., Koroknai, B., Pécskay, Z., Trajanova, M., Horváth, P., Vrabec, M., Jelen, B., Balogh, K., Frisch, W., 2008. Miocene emplacement and rapid cooling of the Pohorje pluton at the Alpine-Pannonian-Dinaridic junction, Slovenia Swiss J. Geosci. 101 (1), 255-271.

Folkes, C.B., de Silva, S.L., Wright, H.M., Cas, R.A.F., 2011. Geochemical homogeneity of a long-lived, large silicic system; evidence from the Cerro Galán caldera, NW Argentina. Bull. Volcanol. 73 (10), 1455-1486.

Fülöp, A., 2002. Facies analysis of the volcaniclastic sequence built up above the $15.4 \mathrm{Ma}$ rhyolitic ignimbrites from Gutâi Mts., Eastern Carpathians. Studia Universitatis Babeş-Bolyai Geologia Special Issue 1, 199-206.

Gans, P.B., Mahood, G.A., Schermer, E., 1989. Synextensional magmatism in the basin and range province; a case study from the eastern Great Basin. Geol. Soc. Am. Spec. Pap. $233,1-53$.

Gee, J.S., Kent, D.V., 2007. Source of oceanic magnetic anomalies and the geomagnetic polarity timescale. In: Schubert, G. (Ed.), Treatise on Geophysics. Elsevier, Amsterdam, pp. 455-507.

Gemmer, L., Houseman, G.A., 2007. Convergence and extension driven by lithospheric gravitational instability: evolution of the Alpine-Carpathian-Pannonian system. Geophys. J. Int. 168 (3), 1276-1290.

Gravley, D.M., Deering, C.D., Leonard, G.S., Rowland, J.V., 2016. Ignimbrite flare-ups and their drivers: a New Zealand perspective. Earth Sci. Rev. 162, 65-82.

Gubler, T., Meier, M., Oberli, F., 1992. Bentonites as Time Markers for Sedimentation of the Upper Freshwater Molasses: Geological Observations Corroborated by High Resolution Single Zircon U-Pb Ages. SANW annual assembly, Basel, Abstract 12-13.

Gueguen, E., Doglioni, C., Fernandez, M., 1998. On the post-25Ma geodynamic evolution of the western Mediterranean. Tectonophysics 298 (1-3), 259-269.

Hámor, G., Ravasz-Baranyai, L., Balogh, K., Árva-Sós, E., 1980. A magyarországi miocén riolittufa-szintek radiometrikus kora. In: MÁFI Évi Jelentése 1978-Ról. pp. 65-73.

Handler, R., Ebner, F., Neubauer, F., Bojar, A.V., Hermann, S., 2006. ${ }^{40} \mathrm{Ar} /{ }^{39} \mathrm{Ar}$ dating of Miocene tuffs from the Styrian part of the Pannonian Basin: an attempt to refine the basin stratigraphy. Geol. Carpath. 57 (6), 483-494.

Harangi, S., 2001. Neogene to Quaternary volcanism of the Carpathian-Pannonian region-a review. Acta Geol. Hung. 44, 223-258.

Harangi, S., Downes, H., Kósa, L., Szabó, C., Thirlwall, M.F., Mason, P.R.D., Mattey, D., 2001. Almandine garnet in calc-alkaline volcanic rocks of the northern Pannonian Basin (Eastern-Central Europe): geochemistry, petrogenesis and geodynamic implications. J. Petrol. 42, 1813-1843.

Harangi, S., Downes, H., Seghedi, I., 2006. Tertiary-Quaternary subduction processes and related magmatism in the Alpine-Mediterranean region. In: Gee, D., Stephenson, R.
(Eds.), European Lithosphere Dynamics: Geological Society of London Memoir. vol. 32, pp. 167-190.

Harangi, S., Downes, H., Thirlwall, M., Gméling, K., 2007. Geochemistry, petrogenesis and geodynamic relationships of Miocene Calc-alkaline volcanic rocks in the Western Carpathian Arc, Eastern Central Europe. J. Petrol. 48 (12), 2261-2287.

Harangi, S., Jankovics, , Sági, T., Kiss, B., Lukács, R., Soós, I., 2015. Origin and geodynamic relationships of the Late Miocene to Quaternary alkaline basalt volcanism in the Pannonian Basin, eastern-central Europe. Int. J. Earth Sci. 104, 2007-2032.

Harangi, S., Lenkey, L., 2007. Genesis of the Neogene to Quaternary volcanism in the Carpathian-Pannonian region: role of subduction, extension, and mantle plume. Geol. Soc. Am. Spec. Pap. 418, 67-92.

Harangi, S., Mason, P.R.D., Lukács, R., 2005. Correlation and petrogenesis of silicic pyroclastic rocks in the Northern Pannonian Basin, Eastern-Central Europe: in situ trace element data of glass shards and mineral chemical constraints. J. Volcanol. Geotherm. Res. 143 (4), 237-257.

Harangi, S., Wilson, M., Tonarini, S., 1995. Petrogenesis of Neogene potassic volcanic rocks in the Pannonian Basin. In: Downes, H., Vaselli, O. (Eds.), Neogene and Related Magmatism in the Carpatho-Pannonian Region: Acta Vulcanologica. vol. 7, pp. $125-134$.

Harzhauser, M., Piller, W.E., Steininger, F.F., 2002. Circum-Mediterranean Oligo-Miocene biogeographic evolution - the gastropods' point of view. Palaeogeogr. Palaeoclimatol. Palaeoecol. 183 (1), 103-133.

Hildreth, W., 1981. Gradients in silicic magma chambers: implications for lithospheric magmatism. J. Geophys. Res. Solid Earth 86 (B11), 10153-10192.

Hildreth, W., Moorbath, S., 1988. Crustal contributions to arc magmatism in the Andes of Central Chile. Contrib. Mineral. Petrol. 98 (4), 455-489.

Hildreth, W., Wilson, C.J.N., 2007. Compositional zoning of the bishop tuff. J. Petrol. 48 (5), 951-999.

Hohenegger, J., Ćorić, S., Wagreich, M., 2014. Timing of the Middle Miocene Badenian stage of the Central Paratethys. Geol. Carpath. 55-66.

Hora, J.M., Singer, B.S., Wörner, G., 2007. Volcano evolution and eruptive flux on the thick crust of the Andean Central Volcanic Zone: ${ }^{40} \mathrm{Ar} /{ }^{39} \mathrm{Ar}$ constraints from Volcán Parinacota, Chile. Geol. Soc. Am. Bull. 119 (3-4), 343-362.

Horstwood, M.S.A., Košler, J., Gehrels, G., Jackson, S.E., McLean, N.M., Paton, C., Pearson, N.J., Sircombe, K., Sylvester, P., Vermeesch, P., Bowring, J.F., Condon, D.J., Schoene, B., 2016. Community-derived standards for LA-ICP-MS U-(Th-)Pb geochronology uncertainty propagation, age interpretation and data reporting. Geostand. Geoanal. Res. 40 (3), 311-332.

Horváth, F., 1993. Towards a mechanical model for the formation of the Pannonian Basin. Tectonophysics 226 (1), 333-357.

Horváth, F., Bada, G., Szafián, P., Tari, G., Ádám, A., Cloetingh, S., 2006. Formation and deformation of the Pannonian Basin: constraints from observational data. Geol. Soc Lond. Mem. 32 (1), 191-206.

Horváth, F., Bada, G., Windhoffer, G., Csontos, L., Dombrádi, E., Dövényi, P., Fodor, L. Grenerczy, Gy, Síkhegyi, F., Szafián, P., Székely, B., Tímár, G., Tóth, L., Tóth, T., 2006. A Pannon-medence jelenkori geodinamikájának atlasza: Euro-konform térképsorozat és magyarázó (Atlas of the present-day geodynamics of the Pannonian Basin: Euroconform maps with explanatory text). Magyar. Geofizika 47 (4), 133-137.

Horváth, F., Dövényi, P., Szalay, , Royden, L.H., 1988. Subsidence, thermal, and maturation history of Great Hungarian Plain. In: Royden, L.H., Horváth, F. (Eds.), AAPG Memoir 45. The Pannonian Basin - A Study in Basin Evolution. pp. 355-372.

Horváth, F., Musitz, B., Balázs, A., Végh, A., Uhrin, A., Nádor, A., Koroknai, B., Pap, N., Tóth, T., Wórum, G., 2015. Evolution of the Pannonian Basin and its geothermal resources. Geothermics 53, 328-352.

Houghton, B.F., Wilson, C.J.N., McWilliams, M.O., Lanphere, M.A., Weaver, S.D., Briggs, R.M., Pringle, M.S., 1995. Chronology and dynamics of a large silicic magmatic system: Central Taupo Volcanic Zone, New Zealand. Geology 23 (1), 13-16.

Houseman, G.A., Gemmer, L., 2007. Intra-orogenic extension driven by gravitational in stability: Carpathian-Pannonian orogeny. Geology 35 (12), 1135-1138.

Hughes, G.R., Mahood, G.A., 2011. Silicic calderas in arc settings: characteristics, distribution, and tectonic controls. Geol. Soc. Am. Bull. 123 (7-8), 1577-1595.

Huismans, R.S., Podladchikov, Y.Y., Cloetingh, S., 2001. Dynamic modelling of the transition from passive to active rifting, application to the Pannonian Basin. Tectonics 20, 1021-1039. https://doi.org/10.1029/2001TC900010.

Hüsing, S.K., Cascella, A., Hilgen, F.J., Krijgsman, W., Kuiper, K.F., Turco, E., Wilson, D., 2010. Astrochronology of the Mediterranean Langhian between 15.29 and $14.17 \mathrm{Ma}$. Earth Planet. Sci. Lett. 290 (3), 254-269.

Jolivet, L., Augier, R., Faccenna, C., Negro, F., Rimmele, G., Agard, P., Robin, C., Rossetti, F., Crespo-Blanc, A., 2008. Subduction, convergence and the mode of back-arc extension in the Mediterranean region. Bull. Soc. Geol. Fr. 179 (6), 525-550.

Jolivet, L., Faccenna, C., 2000. Mediterranean extension and the Africa-Eurasia collision. Tectonics 19 (6), 1095-1106.

Kälin, D., Kempf, O., 2009. High-resolution stratigraphy from the continental record of the Middle Miocene Northern Alpine Foreland Basin of Switzerland. N. Jb. Geol. Paläont. (Abh.) 254 (1-2), 177-235.

Karakas, O., Degruyter, W., Bachmann, O., Dufek, J., 2017. Lifetime and size of shallow magma bodies controlled by crustal-scale magmatism. Nat. Geosci. 10 (6), 446-450.

Karakas, O., Dufek, J., 2015. Melt evolution and residence in extending crust: thermal modeling of the crust and crustal magmas. Earth Planet. Sci. Lett. 425, 131-144. 
Konečný, V., Kováč, M., Lexa, J., Šefara, J., 2002. Neogene evolution of the Carpatho-Pannonian region: an interplay of subduction and backarc diapiric uprise in the mantle. European Geophysical Union Stephan Mueller Special Publication Series 1, 105-123.

Kováč, M., Andreyeva-Grigorovich, A., Bajraktarević, Z., Brzobohatý, R., Filipescu, S., Fodor, L., Harzhauser, M., Oszczypko, N., Pavelic, D., Rögl, F., Saftić, B., Sliva, L., Studencka, B., 2007. Badenian evolution of the Central Parathethys sea: paleogeography, climate and eustatic sea level changes. Geol. Carpath. 58, 579-606.

Kovács, I., Falus, G., Stuart, G., Hidas, K., Szabó, C., Flower, M.F.J., Hegedús, E., Posgay, K., Zilahi-Sebess, L., 2012. Seismic anisotropy and deformation patterns in upper mantle xenoliths from the central Carpathian-Pannonian region: Asthenospheric flow as a driving force for Cenozoic extension and extrusion?. Tectonophysics 514-517, $168-179$.

Kovacs, M., Seghedi, I., Yamamoto, M., Fülöp, A., Pécskay, Z., Jurje, M., 2017. Miocene volcanism in the Oas-Gutâi Volcanic Zone, Eastern Carpathians, Romania: relationship to geodynamic processes in the Transcarpathian Basin. Lithos 294-295, 304-318.

Kuiper, K.F., Deino, A., Hilgen, F.J., Krijgsman, W., Renne, P.R., Wijbrans, J.R., 2008. Synchronizing rock clocks of earth history. Science 320 (5875), 500-504.

Lenkey, L., Dövényi, P., Horváth, F., Cloetingh, S., 2002. Geothermics of the Pannonian basin and its bearing on the neotectonics. In: Cloetingh, S., Horváth, F., Bada, G., Lankreier, A.C. (Eds.), Neotectonics and Surface Processes: The Pannonian Basin and Alpine/Carpathian System. EGU Stephan Mueller Special Publication Series, vol. 3, pp. $29-40$.

Less, G., Kovács, S., Pelikán, P., Pentelényi, L., Sásdi, L., 2005. Geology of the Bükk Mountains. Geological Institute of Hungary Budapest 284.

Lexa, J., Konečný, V., 1998. Geodynamic aspects of the Neogene to Quaternary volcanism. In: Rakús, M. (Ed.), Geodynamic Development of the Western Carpathians - Geological Survey of Slovak Republik, Bratislava. pp. 219-240.

Lipman, P.W., Bachmann, O., 2015. Ignimbrites to batholiths: integrating perspectives from geological, geophysical, and geochronological data. Geosphere 11, 705-743.

Lipman, P.W., Prostka, H.J., Christiansen, R.L., 1972. Cenozoic volcanism and plate-tec tonic evolution of the western United States. I. Early and Middle Cenozoic. Phil. Trans. R. Soc. A, Mathematical and Physical Sciences 271 (1213), 217-248.

Lourens, L.J., Hilgen, F.J., Shackleton, N.J., Laskar, J., Wilson, D., 2004. Orbital tuning calibrations and conversions for the Neogene Period. In: Gradstein, F.M., Smith, A.G. (Eds.), A Geologic Time Scale 2004. Cambridge University Press, pp. 469-484.

Lukács, R., Guillong, M., Sliwinski, J., Dunkl, I., Harangi, S., Bachmann, O., 2018. LA-ICP-MS U-Pb zircon geochronology data of the Early to Mid-Miocene syn-extensional massive silicic volcanism in the Pannonian Basin (East-Central Europe). Data in Brief(submitted).

Lukács, R., Harangi, S., Bachmann, O., Guillong, M., Danišík, M., Buret, Y., von Quadt, A., Dunkl, I., Fodor, L., Sliwinski, J., Soós, I., Szepesi, J., 2015. Zircon geochronology and geochemistry to constrain the youngest eruption events and magma evolution of the Mid-Miocene ignimbrite flare-up in the Pannonian Basin, eastern central Europe. Contrib. Mineral. Petrol. 170 (5), 52. https://doi.org/10.1007/s00410-015-1206-8.

Lukács, R., Harangi, S., Mason, P.R.D., Ntaflos, T., 2009. Bimodal pumice populations in the 13.5 Ma Harsány ignimbrite, Bükkalja Volcanic Field, Northern Hungary: syn-eruptive mingling of distinct rhyolitic magma batches?. Central European Geology 52 (1), $51-72$

Lukács, R., Harangi, S., Ntaflos, T., Mason, P.R.D., 2005. Silicate melt inclusions in the phenocrysts of the Szomolya Ignimbrite, Bükkalja Volcanic Field (Northern Hungary): implications for magma chamber processes. Chem. Geol. 223 (1-3), 46-67.

Lukács, R., Harangi, S., Radócz, G., Kádár, M., Pécskay, Z., Ntaflos, T., 2010. A Nyékládháza-1, Miskolc-7 és Miskolc-8 sz. fúrások miocén vulkáni kôzetei és párhuzamosításuk a Bükkalja vulkáni képződményeivel. Foldtani Kozlony 140 (1), $31-48$

Lustrino, M., Duggen, S., Rosenberg, C.L., 2011. The Central-Western Mediterranean: anomalous igneous activity in an anomalous collisional tectonic setting. Earth Sci. Rev. 104, 1): 1-40.

Lustrino, M., Fedele, L., Melluso, L., Morra, V., Ronga, F., Geldmacher, J., Duggen, S., Agostini, S., Cucciniello, C., Franciosi, L., Meisel, T., 2013. Origin and evolution of Cenozoic magmatism of Sardinia (Italy). A combined isotopic ( $\mathrm{Sr}-\mathrm{Nd}-\mathrm{Pb}-\mathrm{O}-\mathrm{Hf}-\mathrm{Os}$ ) and petrological view. Lithos 180-181, 138-158.

Lustrino, M., Morra, V., Fedele, L., Franciosi, L., 2009. Beginning of the Apennine subduction system in central western Mediterranean: constraints from Cenozoic "orogenic" magmatic activity of Sardinia, Italy. Tectonics 28 (5)https://doi.org/10.1029/ 2008TC002419.

Lustrino, M., Wilson, M., 2007. The circum-Mediterranean anorogenic Cenozoic igneous province. Earth Sci. Rev. 81 (1-2), 1-65.

Magyar, I., Geary, D.H., Müller, P., 1999. Paleogeographic evolution of the Late Miocene Lake Pannon in Central Europe. Palaeogeogr. Palaeoclimatol. Palaeoecol. 147 (3), 151-167.

Marillo-Sialer, E., Woodhead, J., Hergt, J., Greig, A., Guillong, M., Gleadow, A., Evans, N., Paton, C., 2014. The zircon 'matrix effect': evidence for an ablation rate control on the accuracy of U-Pb age determinations by LA-ICP-MS. J. Anal. At. Spectrom. 29 (6), 981-989.

Markovic, F., 2017. Miocene Tuffs From the North Croatian Basin. Unpublished PhD Thesis (in Croatian). Faculty of Science, University of Zagreb, Zagreb, 174.
Márton, E., Fodor, L., 1995. Combination of palaeomagnetic and stress data—a case study from North Hungary. Tectonophysics 242 (1), 99-114.

Márton, E., Márton, P., 1996. Large scale rotations in North Hungary during the Neogene as indicated by paleomagnetic data. In: Morris, A., Tarling, D. (Eds.), Paleomagnetism and Tectonics of the Mediterranean Region. vol. 105, Geol. Society Spec. Publ., pp. 153-173.

Márton, E., Pécskay, Z., 1998. Complex evaluation of paleomagnetic and K/Ar isotope data of the miocene ignimbritic volcanics in the Bukk Foreland, Hungary. Acta Geol. Hung. 41 (4), 467-476.

Márton, E., Zelenka, T., Márton, P., 2007. Paleomagnetic correlation of Miocene pyroclastics of the Bükk Mts and their forelands. Central European Geology 50 (1), 47-57.

Matenco, L., Radivojević, D., 2012. On the formation and evolution of the Pannonian Basin: constraints derived from the structure of the junction area between the Carpathians and Dinarides. Tectonics 31, TC6007https://doi.org/10.1029/ 2012 TC003206.

Mattei, M., Riggs, N.R., Giordano, G., Guarnieri, L., Cifelli, F., Soriano, C.C., Jicha, B., Jasim, A., Marchionni, S., Franciosi, L., Tommasini, S., Porreca, M., Conticelli, S., 2014. Geochronology, geochemistry and geodynamics of the Cabo de Gata volcanic zone, Southeastern Spain. Ital. J. Geosci. 133 (3), 341-361.

McCulloch, M.T., Kyser, T.K., Woodhead, J.D., Kinsley, L., 1994. Pb-Sr-Nd-O isotopic constraints on the origin of rhyolites from the Taupo Volcanic Zone of New Zealand: evidence for assimilation followed by fractionation from basalt. Contrib. Mineral. Petrol. 115 (3), 303-312.

McDonough, W.F., Sun, S.s., 1995. The composition of the Earth. Chem. Geol. 120 (3), 223-253.

Miller, J.S., Matzel, J.E.P., Miller, C.F., Burgess, S.D., Miller, R.B., 2007. Zircon growth and recycling during the assembly of large, composite arc plutons. J. Volcanol. Geotherm. Res. 167 (1), 282-299.

Mundula, F., Cioni, R., Rizzo, R., 2009. A simplified scheme for the description of textura features in Welded Ignimbrites: the example of San Pietro Island (Sardinia, Italy). Ital J. Geosci. 128 (3), 615-627.

Nehyba, S., Roetzel, R., 1999. Lower Miocene Volcaniclastics in South Moravia and Lower Austria. Jahrb. Geol. Bundesanst. 140 (4), 473-490.

Nemčok, M., Lexa, J., 1990. Evolution of the basin and range structure around the Ziar mountain range. Geologicky Zbornik 41 (3), 229-258.

Nemčok, M., Pospisil, L., Lexa, J., Donelick, R.A., 1998. Tertiary subduction and slab break-off model of the Carpathian-Pannonian region. Tectonophysics 295, 307-340.

Pálfy, J., Mundil, R., Renne, P.R., Bernor, R.L., Kordos, L., Gasparik, M., 2007. U-Pb and ${ }^{40} \mathrm{Ar} /{ }^{39} \mathrm{Ar}$ dating of the Miocene fossil track site at Ipolytarnóc (Hungary) and its implications. Earth Planet. Sci. Lett. 258 (1), 160-174.

Pantó, G., 1963. Ignimbrites of Hungary with regard to their genetics and classification. Bull. Volcanol. 25 (1), 175-181.

Pantó, G., 1965. Miozäne tuffhorizonte Ungarns. Acta Geol. Hung. 9, 225-233.

Peccerillo, A., 2005. Plio-Quaternary Volcanism in Italy: Petrology, Geochemistry, Geodynamics. Springer, Berlin-New York, 365.

Pécskay, Z., Lexa, J., Szakács, A., Seghedi, I., Balogh, K., Konečny, V., Zelenka, T., Kovacs, M., Póka, T., Fulop, A., Márton, E., Panaiotu, C., Cvetkovic, V., 2006. Geochronology of Neogene magmatism in the Carpathian arc and intra-Carpathian area. Geol. Carpath. 57 (6), 511-530

Petrik, A., 2016. Cenozoic Structural Evolution of the Southern Bükk Foreland. Ph.D Dissertation (in Hungarian). Eötvös University, Department of Applied and Physical Geology, Budapest, 264.

Petrik, A., Beke, B., Fodor, L., 2014. Combined analysis of faults and deformation bands reveals the Cenozoic structural evolution of the southern Bükk foreland (Hungary) Tectonophysics 633, 43-62. https://doi.org/10.1016/j.tecto.2014.06.029.

Petrik, A., Beke, B., Fodor, L., Lukács, R., 2016. Cenozoic structural evolution of the south western Bükk Mts. and the southern part of the Darnó Deformation Belt (NE Hungary). Geol. Carpath. 67 (1), 83-104.

Póka, T., 1988. Neogene and Quaternary volcanism of the Carpathian-Pannonian region: changes in chemical composition and its relationship to basin formation. In: Royden, L.H., Horváth, F. (Eds.), The Pannonian Basin. A Study in Basin Evolution. AAPG Memoirs. vol. 45, pp. 257-277.

Ratté, J.C., Marvin, R.F., Naeser, C.W., Bikerman, M., 1984. Calderas and ash flow tuffs of the Mogollon Mountains, southwestern New Mexico. J. Geophys. Res. Solid Earth 89 (B10), 8713-8732.

Ravasz, Cs, 1987. Neogene volcanism in Hunagry. Annales Hungariae Geologie Institute 70, 275-279.

Reid, M.R., 2008. How long does it take to supersize an eruption?. Elements 4 (1), 23-28.

Reid, M.R., Coath, C.D., Mark Harrison, T., McKeegan, K.D., 1997. Prolonged residence times for the youngest rhyolites associated with Long Valley Caldera: ${ }^{230} \mathrm{Th}-{ }^{238} \mathrm{U}$ ion microprobe dating of young zircons. Earth Planet. Sci. Lett. 150 (1-2), 27-39.

Riley, P., Tikoff, B., Hildreth, W., 2012. Transtensional deformation and structural control of contiguous but independent magmatic systems: Mono-Inyo Craters, Mammoth Mountain, and Long Valley Caldera, California. Geosphere 8 (4), 740-751.

Riller, U., Petrinovic, I., Ramelow, J., Strecker, M., Oncken, O., 2001. Late Cenozoic tectonism, collapse caldera and plateau formation in the central Andes. Earth Planet. Sci. Lett. 188 (3), 299-311.

Rocholl, A., Böhme, M., Guenther, D., Höfer, H., Ulbig, A., 2008. Prevailing stratospheric easterly wind direction in the Paratethys during the Lower Badenian: Ar-Arand Nd-isotopic evidence from rhyolitic ash layers in the Upper Freshwater Molasse, S-Germany. Geophys. Res. Abstr. 10, (EGU2008-A-08747 2008). 
Rocholl, A., Schaltegger, U., Gilg, H.A., Wijbrans, J., Böhme, M., 2017. The age of volcanic tuffs from the Upper Freshwater Molasse (North Alpine Foreland Basin) and their possible use for tephrostratigraphic correlations across Europe for the Middle Miocene. Int. J. Earth Sci. https://doi.org/10.1007/s00531-017-1499-0.

Roetzel, R., de Leeuw, A., Mandic, O., Márton, E., Nehyba, S., Kuiper, K.F., Scholger, R., Wimmer-Frey, I., 2014. Lower Miocene (Upper Burdigalian, Karpatian) volcanic ashfall at the south-eastern margin of the Bohemian Massif in Austria - new evidence from ${ }^{40} \mathrm{Ar} /{ }^{39} \mathrm{Ar}$-dating, palaeomagnetic, geochemical and mineralogical investigations. Austrian Journal of Earth Sciences 107 (2), 2-22.

Rögl, F., 1999. Mediterranean and Paratethys. Facts and hypotheses of an Oligocene to Miocene paleogeography (short overview). Geol. Carpath. 50 (4), 339-349.

Royden, L.H., 1993. Evolution of retreating subduction boundaries formed during continental collision. Tectonics 12 (3), 629-638.

Royden, L.H., Horváth, F., Burchfiel, B.C., 1982. Transform faulting, extension, and subduction in the Carpathian Pannonian region. Geol. Soc. Am. Bull. 93 (8), 717-725.

Royden, L.H., Horváth, F., Nagymarosy, A., Stegena, L., 1983. Evolution of the Pannonian Basin system. 2. Subsidence and thermal history. Tectonics 2, 91-137.

Sachsenhofer, R.F., Dunkl, I., Hasenhüttl, C., Jelen, B., 1998. Miocene thermal history of the southwestern margin of the Styrian Basin: coalification and fission track data from the Pohorje/Kozjak area (Slovenia). Tectonophysics 297, 17-29.

Sant, K., Palcu, D.V., Mandic, O., Krijgsman, W., 2017. Changing seas in the Early-Middle Miocene of Central Europe: a Mediterranean approach to Paratethyan stratigraphy. Terra Nova 29 (5), 273-281.

Saxby, J., Gottsmann, J., Cashman, K., Gutiérrez, E., 2016. Magma storage in a strike-slip caldera. Nat. Commun. 7, 12295.

Schmitt, A.K., 2009. Quaternary Geochronology by SIMS. Mineralogical Association of Canada Short Course 41, Toronto, May 2009. 109-131.

Schmitt, A.K., Danišík, M., Evans, N.J., Siebel, W., Kiemele, E., Aydin, F., Harvey, J.C., 2011. Acigöl rhyolite field, Central Anatolia (part 1): high-resolution dating of eruption episodes and zircon growth rates. Contrib. Mineral. Petrol. 162 (6), 1215-1231.

Schoene, B., Condon, D.J., Morgan, L., McLean, N., 2013. Precision and accuracy in geochronology. Elements 9 (1), 19-24.

Schoene, B., Latkoczy, C., Schaltegger, U., Günther, D., 2010. A new method integrating high-precision $\mathrm{U}-\mathrm{Pb}$ geochronology with zircon trace element analysis $(\mathrm{U}-\mathrm{Pb}$ TIMS-TEA). Geochim. Cosmochim. Acta 74 (24), 7144-7159.

Seghedi, I., Downes, H., 2011. Geochemistry and tectonic development of Cenozoic magmatism in the Carpathian-Pannonian region. Gondwana Res. 20 (4), 655-672.

Seghedi, I., Downes, H., Harangi, S., Mason, P.R.D., Pécskay, Z., 2005. Geochemical response of magmas to Neogene-Quaternary continental collision in the Carpathian-Pannonian region: a review. Tectonophysics 410 (1), 485-499.

Seghedi, I., Downes, H., Szakács, A., Mason, P.R.D., Thirlwall, M.F., Roşu, E., Pécskay, Z., Márton, E., Panaiotu, C., 2004. Neogene-Quaternary magmatism and geodynamics in the Carpathian-Pannonian region: a synthesis. Lithos 72 (3-4), 117-146.

Self, S., 2006. The effects and consequences of very large explosive volcanic eruptions. Philos. Trans. R. Soc. A Math. Phys. Eng. Sci. 364 (1845), 2073-2097.

Sliwinski, J., Guillong, M., Liebske, C., Dunkl, I., von Quadt, A., Bachmann, O., 2017. Improved accuracy of LA-ICP-MS U-Pb ages in Cenozoic zircons by alpha dose correction. Chem. Geol. 472, 8-21.

Spinks, K.D., Acocella, V., Cole, J.W., Bassett, K.N., 2005. Structural control of volcanism and caldera development in the transtensional Taupo Volcanic Zone, New Zealand. J. Volcanol. Geotherm. Res. 144 (1-4), 7-22.

Steininger, F., Muller, C., Rögl, F., 1988. Correlation of Central Paratethys, Eastern Paratethys, and Mediterranean Neogene stages. In: Royden, L.H., Horvath, F. (Eds.), The Pannonian Basin, a Study in Basin Evolution. AAPG Memoir. vol. 45, American Association of Petroleum Geologists, pp. 79-87.

Szabó, C., Harangi, S., Csontos, L., 1992. Review of Neogene and quaternary volcanism of the Carpathian-Pannonian region. Tectonophysics 208 (1), 243-256.

Szakács, A., Fülöp, A., 2002. Correlating Badenian rhyolitic pyroclastics of the Western Gutai Mts. with the Dej Tuff Complex. Romanian Journal of Mineral Deposits 80, 117-121.
Szakács, A., Márton, E., Póka, T., Zelenka, T., Pécskay, Z., Seghedi, I., 1998. Miocene acidic explosive volcanism in the Bukk Foreland, Hungary: identifying eruptive sequences and searching for source locations. Acta Geol. Hung. 41 (4), 413-435.

Szakács, A., Pécskay, Z., Silye, L., Balogh, K., Vlad, D., Fülöp, A., 2012. On the age of the Dej Tuff, Transylvanian Basin, Romania. Geol. Carpath. 63, 138-148.

Tari, G., 1988. Strike-slip origin of the Vatta-Maklár trough. Acta Geol. Hung. 31, 101-109.

Tari, G., Dövényi, P., Dunkl, I., Horváth, F., Lenkey, L., Stefanescu, M., Szafián, P., Tóth, T., 1999. Lithospheric structure of the Pannonian Basin derived from seismic, gravity and geothermal data. In: Durand, B., Jolivet, L., Horváth, F., Séranne, M. (Eds.), The Mediterranean Basins: Tertiary Extension Within Alpine Orogen. vol. 156, Geological Society, London, Special Publications, pp. 215-250, (1).

Thompson, A.B., Matile, L., Ulmer, P., 2002. Some thermal constraints on crustal assimilation during fractionation of hydrous, mantle-derived magmas with examples from central alpine batholiths. J. Petrol. 43 (3), 403-422.

Thouret, J.-C., Jicha, B.R., Paquette, J.-L., Cubukcu, E.H., 2016. A 25 Myr chronostratigraphy of ignimbrites in south Peru: implications for the volcanic history of the Central Andes. J. Geol. Soc.

Tibaldi, A., 1992. The role of transcurrent intra-arc tectonics in the configuration of a volcanic arc. Terra Nova 4 (5), 567-577.

Török, K., Dégi, J., Szép, A., Marosi, Gy, 2005. Reduced carbonic fluids in mafic granulite xenoliths from the Bakony-Balaton Highland Volcanic Field, W-Hungary. Chem. Geol. 223, 93-108.

Unger, H.J., Fiest, W., Niemeyer, A., 1990. Die Bentonite der Ostbayerischen Molasse und Ihre Beziehungen zu den Vulkaniten des Pannonischen Beckens. Schweizerbart'sche Verlagsbuchhandlung, Stuttgart.

Ustaszewski, K., Schmid, S., Fügenschuh, B., Tischler, M., Kissling, E., Spakman, W., 2008. A map-view restoration of the Alpine-Carpathian-Dinaridic system for the early Miocene. Swiss J. Geosci. 101 (Suppl. 1), 273-294. https://doi.org/10.1007/ s00015-008-1288-7.

Vermeesch, P., 2012. On the visualisation of detrital age distributions. Chem. Geol. 312-313, 190-194.

Walker, J.B.A., Bergantz, G.W., Otamendi, J.E., Ducea, M.N., Cristofolini, E.A., 2015. A MASH zone revealed: the mafic complex of the Sierra Valle Fértil. J. Petrol. 56 (9), 1863-1896.

Wendt, I., Carl, C., 1991. The statistical distribution of the mean squared weighted deviation. Chem. Geol. Isot. Geosci. Section 86 (4), 275-285.

Wilson, C.J.N., Gravley, D.M., Leonard, G.S., Rowland, J.V., 2009. Volcanism in the central Taupo Volcanic Zone, New Zealand: tempo, styles and controls. In: Thordarson, T., Self, S., Larsen, G., Rowland, S.K., Hoskuldsson, A. (Eds.), Studies in Volcanology: The Legacy of George Walker. Special Publications of IAVCEI, vol. 2, pp. 225-247.

Wilson, C.J.N., Houghton, B.F., McWilliams, M.O., Lanphere, M.A., Weaver, S.D., Briggs, R.M., 1995. Volcanic and structural evolution of Taupo Volcanic Zone, New Zealand: a review. J. Volcanol. Geotherm. Res. 68, 1): 1-28.

Wilson, C.J.N., Rowland, J.V., 2016. The volcanic, magmatic and tectonic setting of the Taupo Volcanic Zone, New Zealand, reviewed from a geothermal perspective. Geothermics 59, 168-187, Part B.

Wilson, M., Bianchini, G., 1999. Tertiary-Quaternary magmatism within the Mediterranean and surrounding regions. In: Durand, B., Jolivet, L., Horváth, F., Séranne, M. (Eds.), The Mediterranean Basins: Tertiary Extension Within the Alpine Orogen. vol. 156, Geological Society, London, Special Publication, pp. 141-168.

Wotzlaw, J.-F., Hüsing, S.K., Hilgen, F.J., Schaltegger, U., 2014. High-precision zircon $\mathrm{U}-\mathrm{Pb}$ geochronology of astronomically dated volcanic ash beds from the Mediterranean Miocene. Earth Planet. Sci. Lett. 407, 19-34.

Zachos, J., Pagani, M., Sloan, L., Thomas, E., Billups, K., 2001. Trends, rhythms, and aberrations in global climate 65 Ma to present. Science 292 (5517), 686-693. 